\title{
Use of Biomarkers in Chronic Obstructive Pulmonary Disease: Clinical Implications
}

\author{
Ji-Yong Moon, MD, PhD ${ }^{1,2}$, Yu Ji Cho, MD, PhD ${ }^{1,3}$, Don D. Sin, MD, MPH ${ }^{1,4}$
}

${ }^{1}$ Centre for Heart and Lung Innovation (James Hogg Research Centre), St. Paul's Hospital and the Institute for Heart and Lung Health, University of British Columbia, Vancouver, BC, Canada; ${ }^{2}$ Department of Internal Medicine, Hanyang University College of Medicine, Seoul, Korea; ${ }^{3}$ Division of Respiratory and Critical Care Medicine, Department of Internal Medicine, Gyeongsang National University College of Medicine, Jinju, Korea; ${ }^{4}$ Division of Respiratory Medicine (Department of Medicine), University of British Columbia, Vancouver, BC, Canada

\section{ABSTRACT}

Chronic obstructive pulmonary disease (COPD) is characterised by airflow limitation, which may be progressive and leads to considerable morbidity and mortality. Aside from lung function measurements, there are no biomarkers that are routinely used clinically in the care of patients with COPD. Biomarker is commonly defined as a "characteristic that is objectively measured and evaluated as an indicator of normal biological processes, pathogenic processes, or pharmacologic responses to a therapeutic intervention". Discovery and implementation of biomarkers may enhance the precision of COPD diagnosis, assessment of its risk and severity, response to therapy, and predict progression, enabling personalised health in COPD. In this review, we summarise recent advances in COPD biomarkers and discuss their clinical implications. (BRN Rev. 2018;4:84-107)

Corresponding author: Don Sin, Don.Sin@hli.ubc.ca

Key words: Biomarkers. Chronic obstructive pulmonary disease. Personalised medicine. 


\section{INTRODUCTION}

Chronic obstructive pulmonary disease (COPD) is an inflammatory lung disease, which has a significant systemic component that contributes to its overall morbidity and mortality. The burden $^{1}$ and mortality ${ }^{2}$ of COPD is increasing, but many COPD patients remain under- or undiagnosed $^{3}$. COPD is a major public health problem worldwide. Identification and implementation of biomarkers to diagnose, predict and prognose COPD patients would enable precision health and improve health outcomes of COPD patients. However, to date, other than lung function measurements, there are no widely used clinical biomarkers to guide management of COPD patients.

Although there is no universally accepted definition of a biomarker, the National Institutes of Health (NIH) Biomarkers Definitions Working Group defines biomarker as a "characteristic that is objectively measured and evaluated as an indicator of normal biological processes, pathogenic processes, or pharmacologic responses to therapeutic interventions ${ }^{\prime \prime 4}$. In theory, an ideal biomarker is one that is safe, accurate, inexpensive, easy to measure, modifiable with therapy, and actionable. Similar to drug development, biomarker development requires a robust pipeline including discovery, validation, assay migration, optimization and clinical implementation that involves in most cases a stringent randomised controlled trial demonstrating improvement of patient outcomes in a cost-effective manner ${ }^{5,6}$. Based on their putative roles in the clinic, biomarkers may be categorised as prognostic, predictive, or response markers ${ }^{7}$. The potential applications of these biomarkers in COPD are shown in figure 1 .
Biomarkers can be ascertained in any tissue but ultimately must reflect the pathogenic process of the disease in question. Common sources for biomarker discovery in COPD include blood, sputum, saliva, exhaled condensates, urine, and lung tissues obtained by surgical or bronchoscopic procedures. A biomarker may be a single measurement or consist of multiple components that are individually measured and then integrated together using sophisticated statistical or network analysis; it may be derived based on a priori knowledge of pathophysiology (i.e. candidate biomarker approach) or in an unbiased (unsupervised) fashion using genome-wide analysis.

\section{BLOOD BIOMARKERS}

To date, most of the biomarker efforts in COPD have relied on blood as the source of biomarker discovery. Blood is a very attractive source of biomarkers because it is easy and safe to obtain, and blood tests (once fully developed from the original biomarker work) are often highly reproducible and accurate. The downside of blood biomarkers is that the biomarker signal may not accurately reflect the disease process in the lungs or may be so weak (i.e. have high signal-to-noise ratio) that it cannot be deployed for patient care. Nevertheless, given the advantages of blood sampling, there has been considerable interest and progress in ascertaining blood-based biomarkers. These biomarkers are summarised in table 1 and table 2 and discussed below.

\section{Cellular biomarkers in blood}

One of the most common biomarkers that have been evaluated to date has been total white 


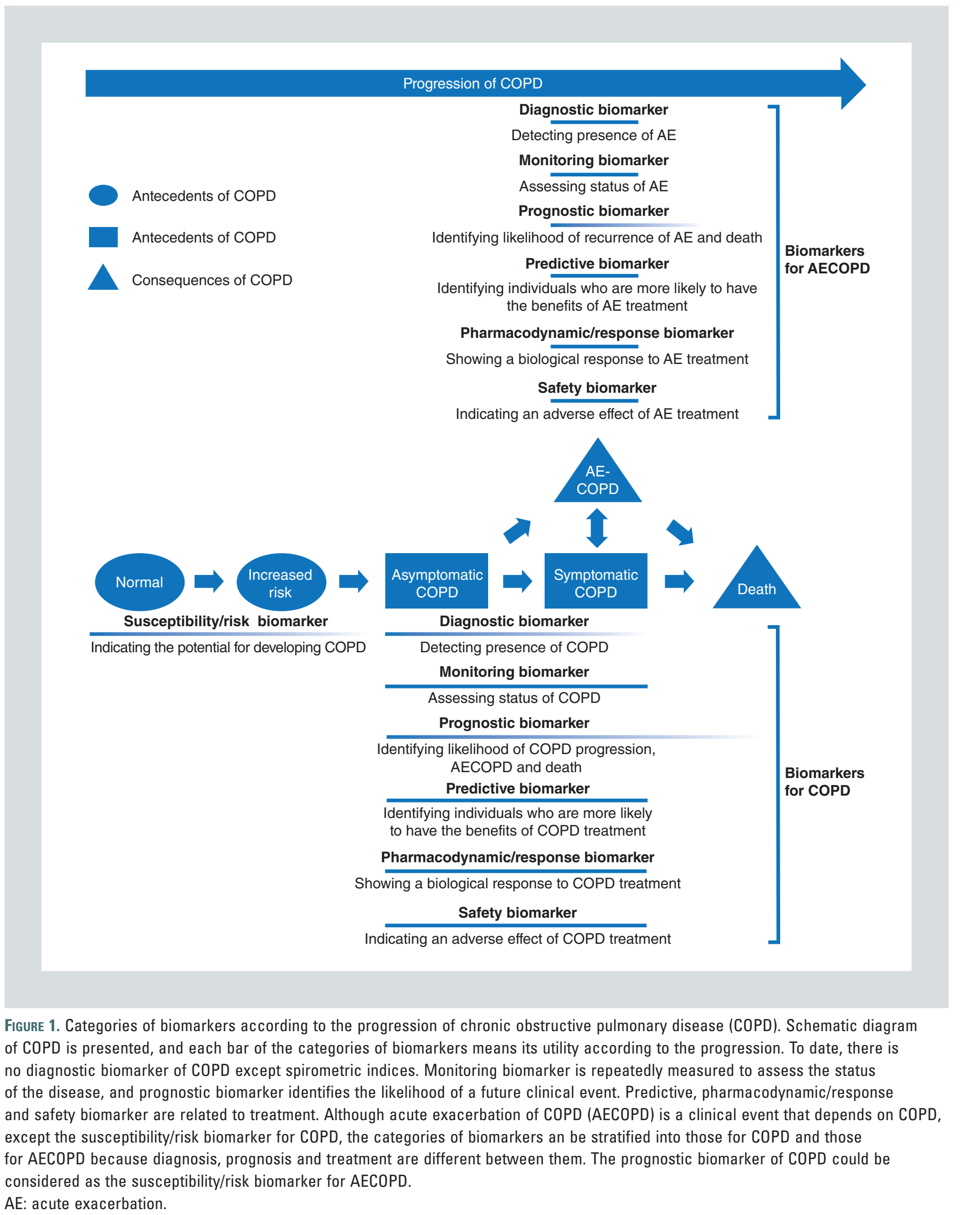


TABLE 1. Cellular biomarkers in blood and their main findings according to the categories

\begin{tabular}{|c|c|c|c|c|c|c|c|}
\hline & $\begin{array}{l}\text { Susceptibility } \\
\text { (future } \\
\text { risk } \\
\text { of COPD) }\end{array}$ & $\begin{array}{c}\text { Diagnosis } \\
\text { of COPD }\end{array}$ & $\begin{array}{l}\text { Monitoring } \\
\text { (severity } \\
\text { of COPD: FEV } \\
\text { or presence } \\
\text { of emphysema) }\end{array}$ & $\begin{array}{l}\text { Prognosis } \\
\text { (risk of mortality, } \\
\text { rate of FEV } \\
\text { decline, } \\
\text { or progression } \\
\text { of emphysema) }\end{array}$ & $\begin{array}{l}\text { Prognosis } \\
\text { (risk of acute } \\
\text { exacerbation) }\end{array}$ & $\begin{array}{l}\text { Prognosis } \\
\text { of acute } \\
\text { exacerbation } \\
\text { (recovery } \\
\text { or mortality } \\
\text { after AE) }\end{array}$ & $\begin{array}{l}\text { Prediction } \\
\text { of response } \\
\text { to therapy }\end{array}$ \\
\hline $\begin{array}{l}\text { Total white } \\
\text { blood } \\
\text { cell } \\
\text { count }\end{array}$ & & & $\begin{array}{l}\text { Negative } \\
\text { association } \\
\text { with } \mathrm{FEV}_{1} \text { and } \\
\mathrm{FVC}^{8}\end{array}$ & $\begin{array}{l}\text { Positive associa- } \\
\text { tion with } \\
\text { mortality }{ }^{10}\end{array}$ & $\begin{array}{l}\text { Positive } \\
\text { association } \\
\text { with future } \\
\text { exacerbation }^{9}\end{array}$ & & \\
\hline Eosinophil & $\begin{array}{l}\text { Negative } \\
\text { association } \\
\text { with } \mathrm{FEV}_{1}{ }^{11}\end{array}$ & & & $\begin{array}{l}\text { Negative } \\
\text { association with } \\
\text { mortality }{ }^{13,14} \text { and } \\
\text { progression of }^{\text {emphysema }}{ }^{12}\end{array}$ & $\begin{array}{l}\text { Positive } \\
\text { association } \\
\text { with severe } \\
\text { exacerba- } \\
\text { tion }^{15}\end{array}$ & $\begin{array}{l}\text { Eosinophilic } \\
\text { phenotype } \\
\text { of } A E: \text { a } \\
\text { shorter } \\
\text { length of } \\
\text { hospitaliza- } \\
\text { tion } \\
\text { following } \\
\text { systemic } \\
\text { steroid }{ }^{27} \\
\text { and a lower } \\
\text { risk of } \\
\text { bacterial } \\
\text { presence }^{29}\end{array}$ & $\begin{array}{l}\text { Effects of ICS: } \\
\text { reduced risk of } \\
\text { pneumonia }{ }^{16} \text {, } \\
\text { unchanged } \\
\text { bacterial load }{ }^{17} \text {, } \\
\text { short-term } \\
\text { improvement of } \\
\mathrm{FEV}_{1}{ }^{18} \text {, reduced } \\
\text { rate of post-BD } \\
\mathrm{FEV}_{1} \text { decline }{ }^{19} \text {, and } \\
\text { better prevention } \\
\text { of } \mathrm{A} \mathrm{E}^{20-23} \text {. } \\
\text { Effects of anti-IL-5: } \\
\text { reduced rate of } \\
\text { moderate to } \\
\text { severe } A \mathrm{E}^{26}\end{array}$ \\
\hline Platelet & & & & & & $\begin{array}{l}\text { Thrombocyto- } \\
\text { sis at admis- } \\
\text { sion: positive } \\
\text { association } \\
\text { with 1-year } \\
\text { mortality and } \\
\text { in-hospital } \\
\text { mortality }\end{array}$ & \\
\hline
\end{tabular}

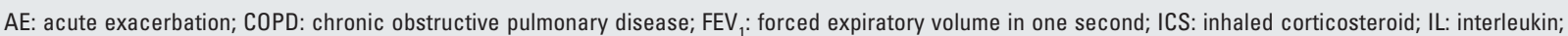
post-BD: post-bronchodilator

blood cell (WBC) count in blood. In COPD, the WBC count has been shown to be negatively associated with forced expiratory volume in one second $\left(\mathrm{FEV}_{1}\right)$ and forced vital capacity (FVC) at a cross-sectional level ${ }^{8}$. During acute exacerbations of COPD (AECOPD), WBC counts increase further ${ }^{9}$. WBC counts also predict 3-year mortality in COPD patients with or without adjustments for confounders ${ }^{10}$. However, owing to the relative poor resolution of the signal, WBC count cannot be used at an individual level to predict future risk of mortality, though at a population level it is a useful prognostic biomarker.

Blood eosinophil count is another commonly used biomarker in COPD. Similar to total WBC counts, at a population level, elevated peripheral eosinophil count is associated with reduced $\mathrm{FEV}_{1}$ over 24 years of follow-up as demonstrated in the Vlagtwedde/Vlaardingen study, which evaluated 3,550 subjects between the ages of 15 and 35 years $^{11}$. On the other hand, in the Evaluation of COPD Longitudinally to Identify 

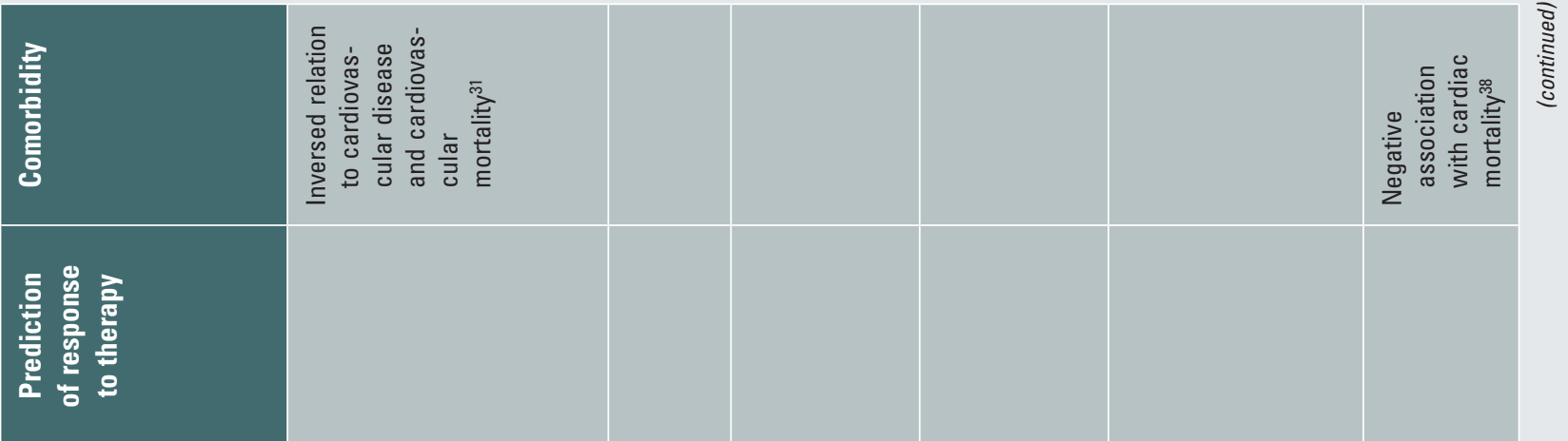

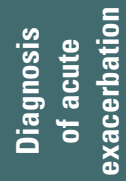

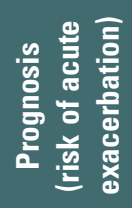

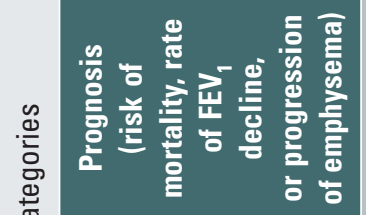

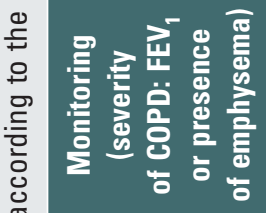

o

泣

है

育

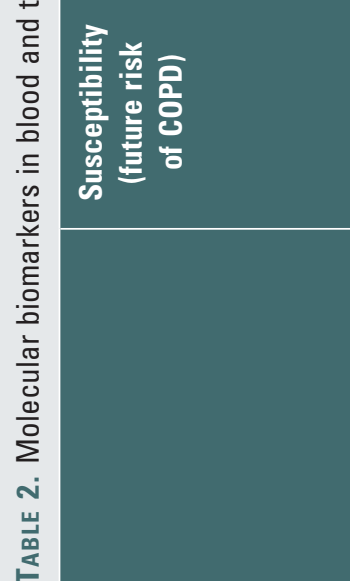

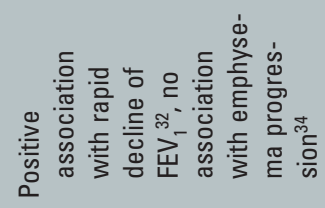

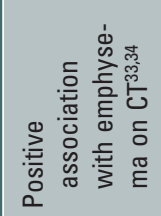

든
$\frac{0}{0}$
흔
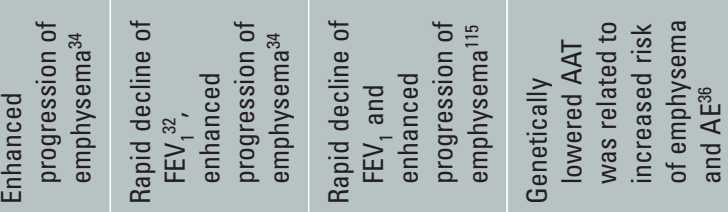

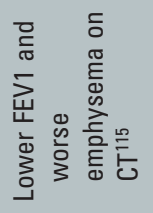

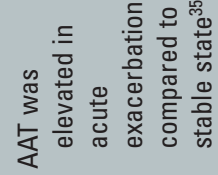

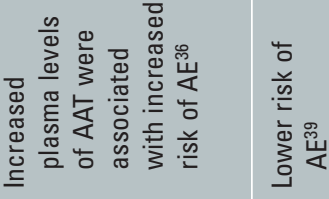

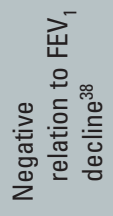

흘

은 응

离离

옹으
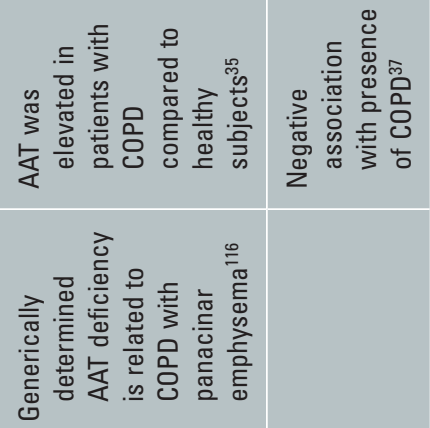

高 

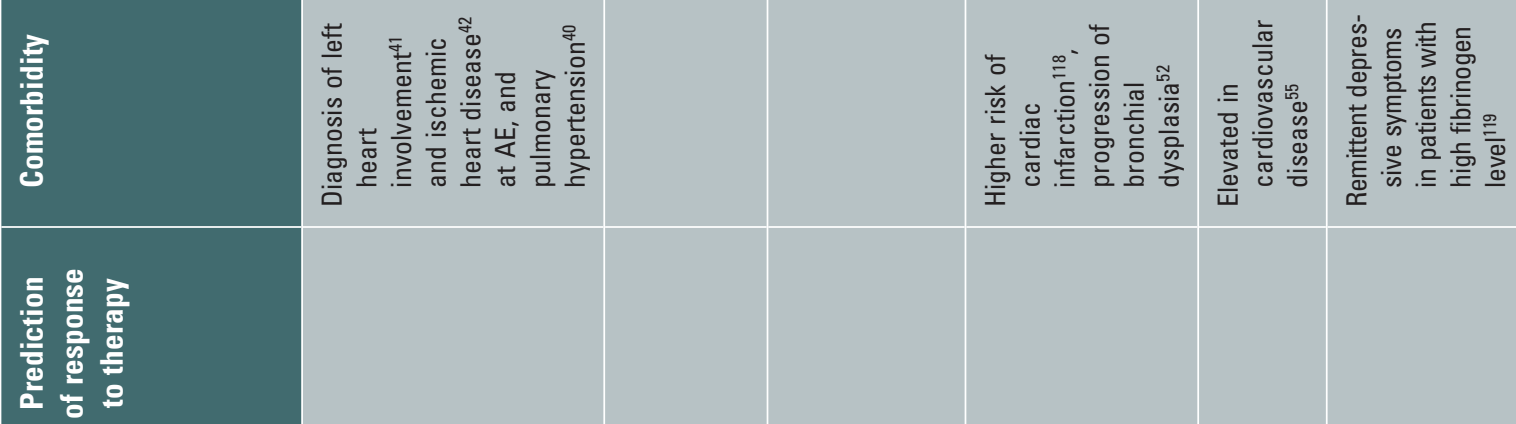

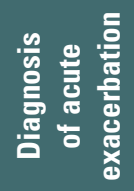

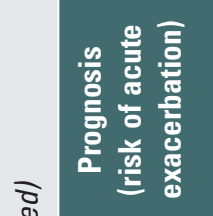

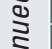

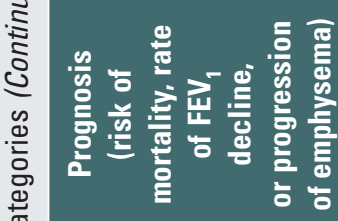

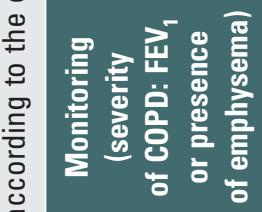

s

言

을 웅

हू

育

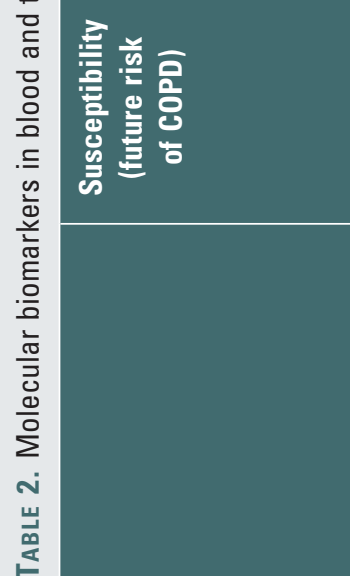

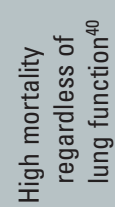

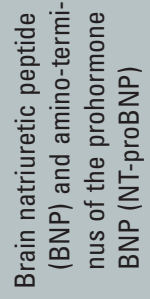

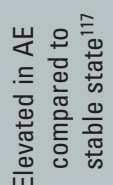

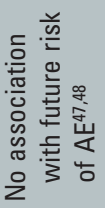

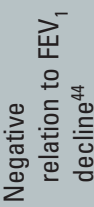

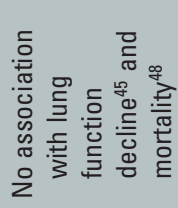

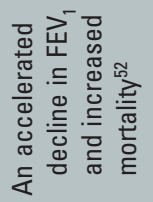

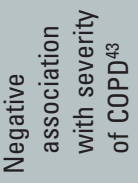

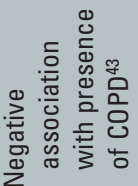

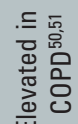

这

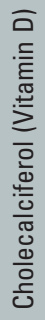

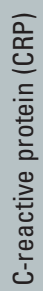

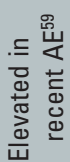

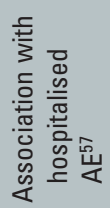

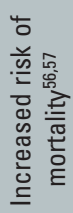

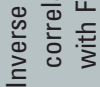

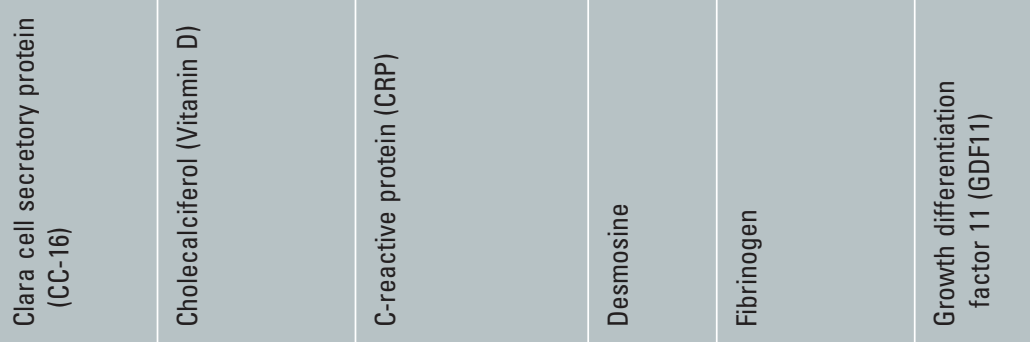




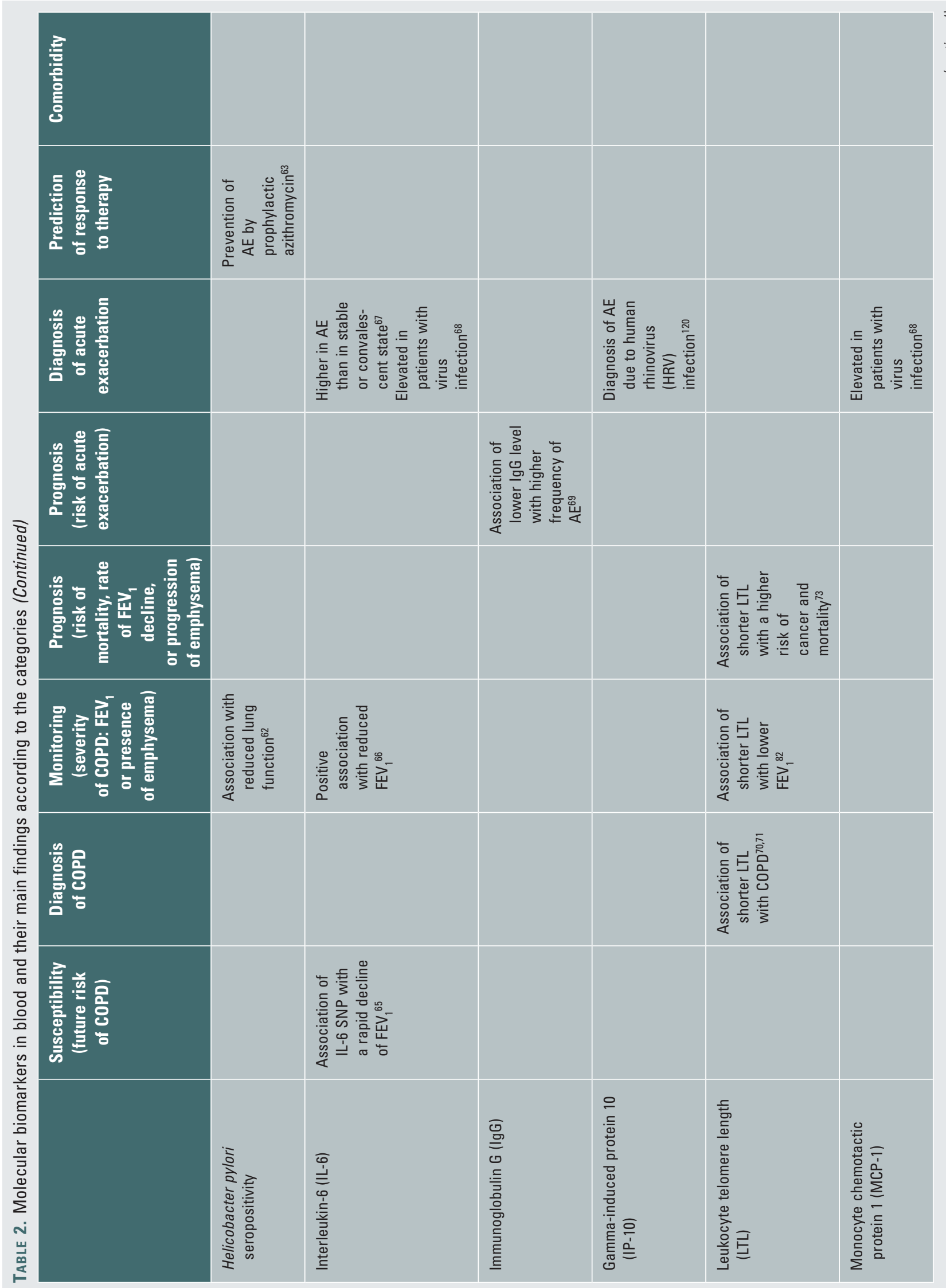



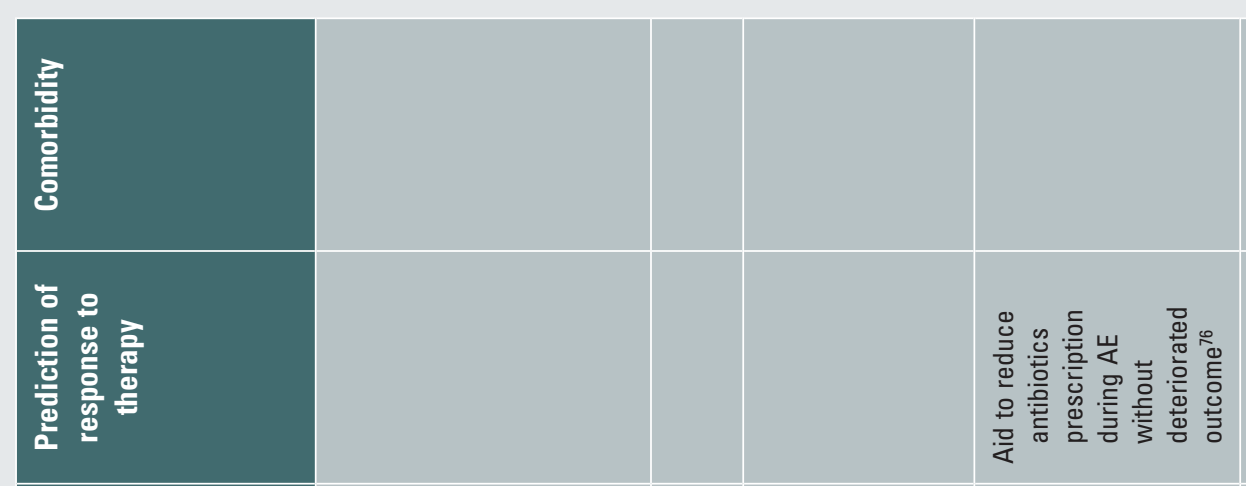

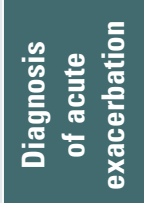

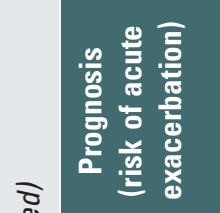

จิ

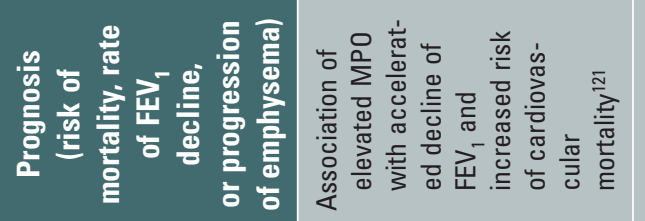
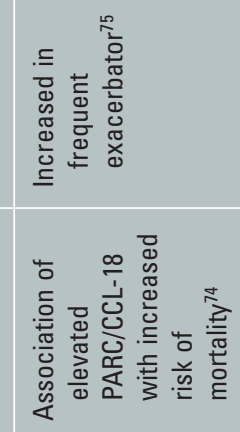

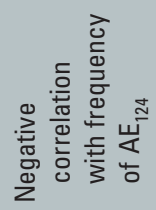

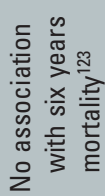

\begin{tabular}{|c|c|c|c|c|c|c|}
\hline 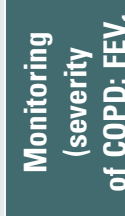 & & & & & & 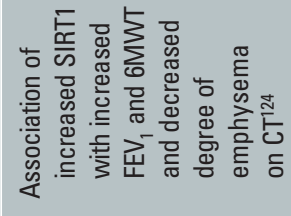 \\
\hline 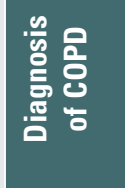 & & 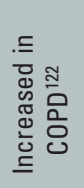 & 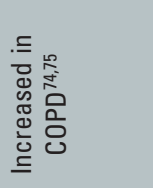 & & & 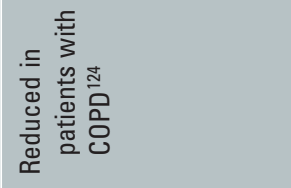 \\
\hline \multirow[t]{2}{*}{ 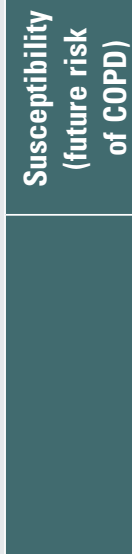 } & & & & & & \\
\hline & 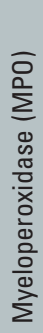 & 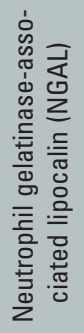 & 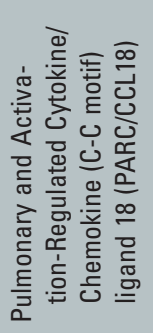 & 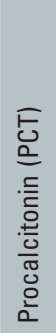 & 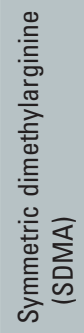 & 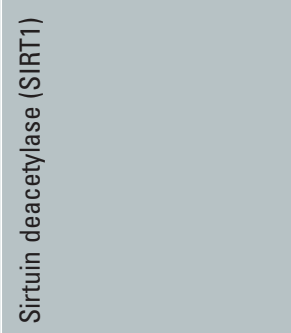 \\
\hline
\end{tabular}




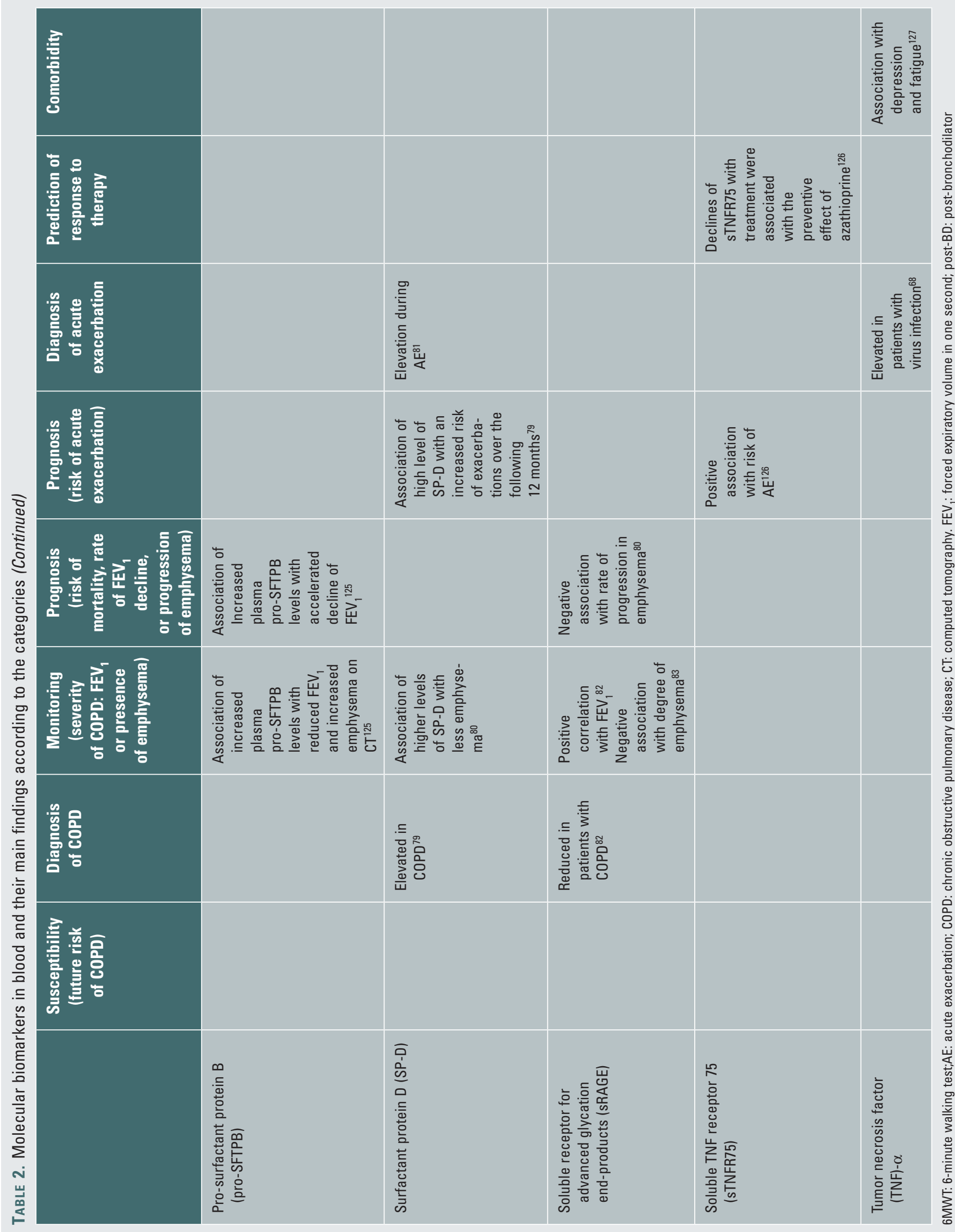


Predictive Surrogate End-points (ECLIPSE) cohort, patients with persistently high blood eosinophils ( $\geq 2 \%$ of WBC) had more favourable clinical features at baseline including higher $\mathrm{FEV}_{1}$, improved health status as reflected in lower St. George's Respiratory Questionnaire (SGRQ) scores, less intense symptoms as evidenced by lower modified Medical Research Council (mMRC) dyspnoea score and a lower rate of emphysema progression compared to those with persistently low or variable blood eosinophil count ${ }^{12}$. Consistent with these findings, in a pragmatic COPD cohort in Spain, patients with persistently high blood eosinophils $(\geq 150 / \mu \mathrm{L})$ demonstrated improved survival compared with those with low $(<150 /$ $\mu \mathrm{L})$ or variable blood eosinophil count ${ }^{13}$. In patients in the COPD History Assessment In SpaiN (CHAIN) cohort and the body-mass index, airflow Obstruction, Dyspnoea, Exercise performance (BODE) cohort, persistent blood eosinophilia ( $\geq 300$ cells $/ \mu \mathrm{L}$ ) over two years was not a risk factor for acute exacerbation (AE) but was a significant predictor of improved survival ${ }^{14}$. In the Copenhagen General Population Study, COPD patients with blood eosinophilia ( $\geq 340$ cells $/ \mu \mathrm{L}$ ) had a 1.76-fold increased risk of severe exacerbation compared to COPD patients without blood eosinophilia after adjusting for confounders ${ }^{15}$. It should be noted that blood eosinophils may not reflect lung tissue expression of eosinophils or airway eosinophilia ${ }^{13}$, which may in part explain the heterogeneity in results across studies that have evaluated the relationship between peripheral eosinophils and COPD outcomes.

Blood eosinophils have also been considered as a response biomarker in COPD. A meta-analysis of ten clinical trials that evaluated the clinical effects of inhaled corticosteroids (ICS) or combination of ICS and long-acting beta-agonists (ICS/LABA) in COPD demonstrated that patients with blood eosinophil counts of less than $2 \%$ of total WBC at pre-randomisation had a higher risk of pneumonia than those with eosinophil counts of $2 \%$ or more ${ }^{16}$. In a clinical trial of ICS/LABA versus LABA to evaluate the change of sputum bacterial load, patients who were treated with ICS and had a lower baseline sputum $(\leq 2 \%)$ or blood eosinophil $(\leq 2 \%)$ showed increased bacterial load after one year of treatment with ICS compared with those without these traits ${ }^{17}$. COPD patients with high blood eosinophils $(>260 / \mu \mathrm{L})$ and high plasma periostin (> $23 \mathrm{ng} / \mathrm{mL})$ levels demonstrated greater improvements in $\mathrm{FEV}_{1}$ (> 12\% and $200 \mathrm{~mL}$ increase from baseline) with a 3-month treatment of ICS/LABA compared with those COPD patients who did not have these features ${ }^{18}$. In the Inhaled Steroids in Obstructive Lung Disease in Europe (ISOLDE) study, which evaluated the effects of ICS for three years, COPD patients with blood eosinophilia $\geq 2 \%$ had a slower rate of post-bronchodilator (post-BD) $\mathrm{FEV}_{1}$ decline by $33.9 \mathrm{~mL} /$ year with fluticasone propionate versus placebo ${ }^{19}$. Recently, post hoc analyses of studies comparing ICS/LABA and LABA demonstrated that increased eosinophil count in blood was associated with improved responses to ICS/LABA ${ }^{20-22}$ and poorer responses to ICS withdrawal ${ }^{23}$. In contrast, in the Effect of Indacaterol Glycopyronium versus Fluticasone Salmeterol on COPD Exacerbations (FLAME) study, which compared the effects of LABA combined with long-acting muscarinic antagonist (LAMA) versus ICS/ LABA, baseline blood eosinophil count did not modify the effects of LABA/LAMA or ICS/ LABA on the rates of COPD exacerbations. However, it is notable that the FLAME study excluded patients who demonstrated a blood 
eosinophil count of $>600$ cells $/ \mu L^{24}$. Benralizumab is an anti-interleukin 5 (IL-5) receptor $\alpha$ monoclonal antibody that reduces exacerbation in patients with eosinophilic asthma. In moderate-to-severe COPD patients who demonstrated sputum eosinophilia $\geq 3 \%$ and had at least one $\mathrm{AE}$ in the previous year, there was a trend towards increased (beneficial) response to benralizumab among patients with blood eosinophilia $\geq 200$ or $\geq 300$ cells $/ \mu L^{25}$. Mepolizumab is a humanised anti-IL-5 monoclonal antibody that has been approved by the Food and Drug Administration (FDA) for the treatment of severe eosinophilic asthma. In COPD patients who had blood eosinophils $\geq 150$ cells $/ \mu \mathrm{L}$ at screening or $\geq 300$ cells $/ \mu \mathrm{L}$ at any point in the previous year and had a history of moderate to severe AECOPD in the year prior to randomisation, treatment with mepolizumab reduced the rate of moderate-to-severe AECOPD compared with placebo ${ }^{26}$. Nevertheless, given the cost of these biologics and the availability of cheaper alternates (e.g., inhaler-based therapy, azithromycin or roflumilast), the role of these targeted anti-eosinophilic therapy in COPD remains uncertain.

Eosinophil has also been evaluated as a possible response biomarker for systemic corticosteroid treatment. In hospitalised AECOPD patients, those who demonstrated an increased eosinophil count in peripheral blood $\geq 200$ cells $/ \mu \mathrm{L}$ or $\geq 2 \%$ of total WBC had lower levels of c-reactive protein (CRP) at admission and experienced shorter lengths of hospitalization following oral corticosteroid treatment than those without this feature ${ }^{27}$. Aaron et al. ${ }^{28}$ showed in 81 patients with COPD that treatment with prednisone (40 mg/d for 10 days) was less likely to fail compared with treatment with etanercept, a tumour necrosis factor $\alpha$ (TNF- $\alpha$ ) antagonist, in patients whose blood eosinophils were $2 \%$ or greater at the time of AECOPD (22\% versus $50 \% ; \mathrm{p}=0.08)$. In contrast, there were no differences in the treatment failure rates between the two treatment groups in patients whose peripheral eosinophil counts were less than $2 \%{ }^{28}$.

Eosinophilic phenotyping may also assist in identifying the aetiology of AECOPD. In the Acute Exacerbation and Respiratory InfectionS in COPD (AERIS) cohort, which consisted of patients with moderate to very severe COPD, those who had high blood eosinophils ( $\geq 2 \%$ ) at baseline demonstrated persistent eosinophilia during AE (and were labelled eosinophilic phenotype). The patients with an eosinophilic phenotype had a lower rate of bacterial infection/colonization in sputum samples during exacerbations compared to those who had a non-eosinophilic phenotype ${ }^{29}$.

However, there are several important limitations to the implementation of peripheral eosinophil count as a response biomarker in COPD. First, although at a population level (or in large therapeutic trials), increased peripheral eosinophil count is associated with improved responses to ICS to prevent exacerbations or oral corticosteroids to prevent treatment failures during AECOPD and may be useful for predicting responses to anti-IL5 therapy, its relatively signal-to-noise ratio makes it difficult to apply this biomarker to predict therapeutic responses at an individual level. Second, there is no consensus on the optimal cut-off that should be used to determine who should and should not receive steroid-based therapy. The cut-offs used to define eosinophilia have varied across different studies. Moreover, many cut-offs that have been employed have been at a level that would be considered "normal" (e.g., 300 cells/uL). 
Until these issues can be resolved, peripheral eosinophil cannot be adopted widely in clinical practice for patient care.

Although less extensively studied than peripheral WBC count or blood eosinophils, platelet counts have also been evaluated as biomarkers in COPD. Thrombocytosis over $400 \times 10^{9}$ cells $/ \mathrm{mm}^{3}$ at admission to hospital for AECOPD has been associated with increased in-hospital and 1 year-mortality. The use of antiplatelet medications including clopidogrel and aspirin has been associated with lower 1 -year mortality in the same study ${ }^{30}$.

\section{Molecular biomarkers in blood}

Adiponectin and leptin are adipokines that are secreted mainly by adipose tissue and associated with inflammation and nutrition. Serum adiponectin concentrations have been shown to be related to respiratory mortality ${ }^{31}$, increased bronchial reactivity ${ }^{31}$, an accelerated decline in lung function ${ }^{31,32}$, and emphysema on computed tomography $(\mathrm{CT})^{33,34}$. Plasma leptin and the leptin/adiponectin ratio were also associated with reduced $\mathrm{FEV}_{1}$ and accelerated progression of emphysema on $\mathrm{CT}^{34}$. However, the associations of adipokines with a decline of $\mathrm{FEV}_{1}$ or progression of emphysema have been discordant among the studies ${ }^{32,34}$.

Alpha-1 antitrypsin (AAT) is an inhibitor of neutrophil elastase. Blood levels of AAT can be used to detect AAT deficiency, which is responsible for COPD in a select number of patients. However, because AAT is an acute phase reactant, it may be elevated during $\mathrm{AECOPD}^{35}$, and increased plasma levels of AAT have been associated with increased risk of $\mathrm{AECOPD}^{36}$.
Bilirubin has anti-oxidant, anti-inflammatory and anti-proliferative properties. After adjusting for other health indicators, a 0.1-mg/dL increase in serum bilirubin levels has been associated with a $6 \%$ decrease in the risk of $\mathrm{COPD}^{37}$. In mild COPD, bilirubin has been positively related to post-BD FEV $\mathrm{FE}_{1}$ and negatively related to the annual decline in $\mathrm{FEV}_{1}$ and risk of death from coronary heart disease following adjustments for baseline demographics, smoking, lung function ${ }^{38}$. Higher bilirubin has also been associated with lower hazard for AECOPD in the MACROlide azithromycin to prevent COPD exacerbations (MACRO) Study ${ }^{39}$.

Brain natriuretic peptide (BNP) and amino-terminus of the prohormone BNP (NT-proBNP) are biomarkers for mechanical stress in the cardiomyocytes related to volume overload and are also raised in the presence of pulmonary hypertension. Elevated BNP ( $>75 \mathrm{pg} / \mathrm{ml})$ has been associated with significant pulmonary hypertension as measured by right heart catheterization and poor survival regardless of the severity of lung function impairment or extent of hypoxemia ${ }^{40}$. An NT-proBNP level of less than $1,000 \mathrm{pg} / \mathrm{ml}$ has been shown to be useful in ruling out left ventricular systolic dysfunction in $\mathrm{AECOPD}^{41}$ and increased NT-proBNP at exacerbation has been noted in patients with ischemic heart disease ${ }^{42}$.

Clara cell secretory protein (CC-16) is a marker of club cell toxicity and its expression in lung and blood is reduced in patients with COPD ${ }^{43}$. In patients with mild-to-moderate COPD, decreased serum CC16 levels have been associated with accelerated decline in $\mathrm{FEV}_{1}$ after adjusting for confounders including age, sex, race, smoking status, airway reactivity, body mass index, and baseline $\mathrm{FEV}_{1}^{44}$. 
Baseline plasma 25-hydroxyvitamin D levels were not shown to be predictive of lung function decline in the Lung Health Study (LHS) cohort $^{45}$, whereas in another healthy male smoker cohort, baseline vitamin $\mathrm{D}$ deficiency $(<20 \mathrm{ng} / \mathrm{mL})$ was associated with lower lung function and accelerated decline in $\mathrm{FEV}_{1}^{46}$. Baseline 25-hydroxyvitamin D (25[OH]D) levels have not been shown to relate to subsequent risk of AECOPD $^{47,48}$ or mortality ${ }^{48}$. Baseline $25(\mathrm{OH}) \mathrm{D}$ has not been associated with the changes in $\mathrm{FEV}_{1}$ after four weeks of ICS treatment ${ }^{49}$.

C-reactive protein (CRP) is an acute phase protein, which rises during acute infectious, inflammatory or neoplastic processes. Serum CRP levels have been shown to be significantly higher (on average) in patients with COPD than in non-smoking or smoking control subjects ${ }^{50}$. A meta-analysis of 5 studies showed that CRP was higher in patients with COPD than in normal controls $^{51}$. In mild-to-moderate COPD, CRP levels have also been associated with accelerated decline in $\mathrm{FEV}_{1}$, as well as all-cause, cardiovascular, and cancer-specific causes of mortality ${ }^{52}$. In patients with a smoking history of 30 or more pack-years and who demonstrated dysplastic lesions larger than $1.2 \mathrm{~mm}$ on bronchoscopic biopsies, plasma CRP > $0.5 \mathrm{mg} / \mathrm{L}$ was associated with increased odds for progression of disease than those with CRP $\leq 0.5 \mathrm{mg} / \mathrm{L}^{52}$. CRP may also predict treatment failure to therapy. In data from 152 patients of the placebo arm of a randomised trial of amoxicillin/clavulanate for exacerbations of mild-to-moderate COPD, the probability of failure without antibiotics was highest in the presence of sputum purulence and high CRP concentration $(\geq 40 \mathrm{mg} / \mathrm{L})^{53}$.

Desmosine is a biomarker of elastin degradation that is a major feature of emphysema and increased arterial stiffness ${ }^{54}$. Plasma desmosine has been shown to be elevated in patients with COPD compared to control subjects, and also increased in COPD patients who also have concomitant cardiovascular diseases. Elevated plasma desmosine has been associated with all-cause mortality but not with emphysema $^{55}$.

Fibrinogen is an acute phase reactant and has been qualified by FDA as a prognostic biomarker for exacerbations and all-cause mortality in patients with COPD. Plasma fibrinogen, on average, has been shown to be higher in patients with COPD than in normal controls ${ }^{51}$ and positively associated with mortality ${ }^{10,56}$. In a pooled analysis of 6,376 COPD patients from five studies, high plasma fibrinogen levels (> $350 \mathrm{mg} / \mathrm{dL}$ ) were associated with an increased risk of hospitalised exacerbations within 12 months (in four studies) of blood draw and death within 36 months (in five studies) of blood draw ${ }^{57}$. Despite this, in an analysis that used Mendelian randomisation, genetically increased levels of fibrinogen were not significantly related to the risk of AECOPD, suggesting that fibrinogen may not be causally involved in this process ${ }^{58}$. In the ECLIPSE cohort, fibrinogen was the most repeatable biomarker among those that relate to AECOPD ${ }^{59}$.

Growth differentiation factor 11 (GDF11) belongs to the transforming growth factor $\beta$ superfamily and is a circulating protein that may retard the aging process. The levels of plasma GDF11 have been shown to be significantly decreased in patients with COPD compared with controls and inversely related to $\mathrm{FEV}_{1}{ }^{60}$. GDF11 could be a predictive biomarker for patients with COPD who might benefit from GDF11 supplementation therapy ${ }^{61}$. 
Seropositivity of Helicobacter pylori, as defined by Helicobacter pylori immunoglobulin G concentrations above $18 \mathrm{DU} / \mathrm{mL}$, has been associated with reduced lung function and increased risk of cardiovascular mortality in patients with mild to moderate $\mathrm{COPD}^{62}$. In the Azithromycin for the Prevention of Exacerbations of COPD (MACRO) study, azithromycin was most effective in reducing the risk of exacerbation in those who were seropositive to Helicobacter pylori ${ }^{6}$. Helicobacter pylori seropositivity may be a biomarker to predict the therapeutic effectiveness of azithromycin in the prevention of AECOPD.

IL-6 is an inflammatory cytokine which could reflect systemic inflammation and is produced by adipocytes, muscles, liver, and lungs ${ }^{64}$. Single nucleotide polymorphisms (SNP) in IL-6 have been associated with a rapid decline of $\mathrm{FEV}_{1}{ }^{65}$. Serum IL-6 levels have also been associated with reduced $\mathrm{FEV}_{1}{ }^{66}$ and rises to even higher concentrations during acute exacerbations ${ }^{67}$. In hospitalised patients with AECOPD, blood levels of inflammatory cytokines including interleukin (IL)-6, TNF- $\alpha$, and monocyte chemotactic protein 1 (MCP-1) have been shown to be elevated in patients with COPD and increase further with acute virus infections ${ }^{68}$.

Serum immunoglobulin G (IgG) levels are promising predictive biomarkers for exacerbation in COPD. In a pooled analysis consisting of data from the MACRO study and the Prospective Randomized Placebo-Controlled Trial of Simvastatin in the Prevention of COPD Exacerbations (STATCOPE) study, approximately one in five patients with COPD had total IgG levels below the limit of normal for an adult $(<7.0 \mathrm{~g} / \mathrm{L})$ and, most importantly, these individuals had two times the risk of AECOPD compared with patients with normal serum IgG levels ${ }^{69}$.

Leukocyte telomere length (LTL) is a biomarker of cellular senescence. Patients with COPD have on average shorter LTL and a higher rate of telomere attrition than control smokers or nonsmokers ${ }^{70,71}$. LTL has been associated with $\mathrm{FEV}_{1}$ and $\mathrm{FEV}_{1} / \mathrm{FVC}$ in patients with $\mathrm{COPD}^{72}$. In the LHS, those with reduced LTL had a higher risk of cancer and total mortality compared with those with normal LTL ${ }^{73}$. LTL could be a risk factor both for COPD and lung cancer.

Pulmonary and activation-regulated cytokine/ chemokine (C-C motif) ligand 18 (PARC/CCL-18) is an inflammatory chemokine produced in the lung. Serum PARC/CCL-18 levels have been shown to be elevated in patients with COPD compared with smoking or non-smoking controls ${ }^{74,75}$, which in turn has been associated with increased risk of mortality ${ }^{74}$ and AECOPD requiring hospitalization in the previous 12 months ${ }^{75}$.

In a meta-analysis of eight trials, procalcitonin (PCT)-based protocols could reduce antibiotic prescription and total antibiotic exposure without worsening clinical outcomes; however, these data should be interpreted cautiously as the overall quality of data was deemed $l^{7}{ }^{76}$. An observational study that used data from a geographical consortium of hospitals demonstrated that decisions to initiate antibiotics therapy or duration of antibiotics treatment on AECOPD were not impacted by PCT testing 77 .

Surfactant protein D (SP-D) is produced by alveolar type II cells and has an immunomodulatory role which is essential to host defenses. Several SNPs in surfactant protein-D (SFTPD) 
have been associated with increased susceptibility to COPD in some but not all cohorts ${ }^{78}$. SP-D is elevated in patients with COPD compared to those without $\mathrm{COPD}^{79}$. Higher plasma levels of SP-D have been associated with less emphysema ${ }^{80}$ but with an increased risk of exacerbations ${ }^{79}$. Serum SP-D levels are also increased in patients during exacerbations ${ }^{81}$.

Soluble receptor for advanced glycation end-products (sRAGE) may be a biomarker of the underlying inflammatory process of COPD. sRAGE levels are generally lower in patients with COPD than in controls and are positively correlated with $\mathrm{FEV}_{1}{ }^{82}$. Furthermore, higher sRAGE levels have been associated with less emphysema ${ }^{80,83}$ and reduced rate of emphysema progression over time ${ }^{80}$.

\section{Multi-component biomarkers in blood}

Biomarker panels consisting of composite signatures are now beginning to emerge as potential blood tests for clinical application. For instance, a higher fibronectin to CRP ratio ( $>150$ ) has been related to increased risk of all-cause mortality ${ }^{84}$. When WBC count, CRP, IL-6, and fibrinogen have been assessed, aggregate score based on all of these components was more predictive of all-cause mortality than individual assays in COPD patients ${ }^{85}$. This also held true for assessing other endpoints such as the risk of myocardial infarction, heart failure, diabetes mellitus, lung cancer, and pneumonia ${ }^{86,87}$. However, some clinical endpoints, which may not be sensitive to inflammation, such as depression, are not responsive to biomarkers of inflammation singly or in aggregate ${ }^{88}$.

Another "panel" of biomarkers is the concurrent measurement of CRP and NT-proBNP. Together they have a higher performance as measured by receiver operating characteristics (ROC) area under the curve (AUC) than CRP alone in diagnosing AECOPD that require hospitalisation ${ }^{89}$. Similarly, combination of two cardiac markers (high-sensitivity troponin I and copeptin) showed better performance in predicting 30 day mortality than individual components ${ }^{89}$.

Other combinations of biomarkers including CC-16, sRAGE, fibrinogen, CRP, and SP-D have been evaluated in COPD and some have shown associations with COPD outcomes including AECOPD, disease progression, and mortality ${ }^{90}$. Although in general this is true, reproducibility of these combinatorial biomarkers has been problematic. Other approaches to combinatorial biomarker discovery are to use a multiplex protein array ${ }^{91-93}$ and to combine biomarkers to clinical parameters ${ }^{10,94,95}$. In one study, investigators measured 143 serum biomarkers using a multiplex immunoassay platform. Of these, 24 proteins demonstrated significant relationships with $\mathrm{FEV}_{1}$, diffusing capacity of carbon monoxide $\left(\mathrm{DL}_{\mathrm{CO}}\right), 6$-minute walk test (6MWT), BODE index or risk of exacerbations ${ }^{93}$.

\section{SPUTUM BIOMARKERS}

Sputum samples may better reflect the inflammatory process in the airways of COPD than blood samples. However, to properly 
collect high quality sputum samples for interrogation, centres must have considerable expertise and resources for sputum induction, processing and evaluation. Another disadvantage is that inflammatory biomarkers measured in sputum generally have lower repeatability than similar molecules measured in blood. Additionally, investigators should be aware that there may also be significant variation in biomarker levels between spontaneously expectorated and induced sputum from the same individual ${ }^{96}$. Sputum biomarkers are summarised according to their category in table 3 and briefly discussed below.

In a cohort of 148 COPD patients with a follow-up of 2.91 years, a high neutrophil count and high sputum IL-6 levels were found to be associated with rapid $\mathrm{FEV}_{1}$ decline ${ }^{67}$. In the ECLIPSE study, there was a weak association between percentage of neutrophils in sputum and $\mathrm{FEV}_{1} \%$ predicted and $\mathrm{SGRQ}^{97}$. In the Subpopulations and Intermediate Outcomes in COPD Study (SPIROMICS) cohort, the high sputum eosinophil group $(\geq 1.25 \%)$ had lower pre- and post-BD $\mathrm{FEV}_{1} \%$, higher emphysema score and more gas trapping on CT scans than those without these features. They were also more likely to experience corticosteroid-requiring AECOPD events than those who had low percentages of eosinophils in their sputum ${ }^{98}$.

Mucin is a macromolecule that consists of mucus and a protein backbone, which together forms a barrier to pathogen invasion in the airways ${ }^{99}$. In patients with severe COPD, mucosal occlusion of small airways is the single best predictor on histology for mortality ${ }^{100}$. Total mucin concentrations have also been associated with severity of airflow obstruction as indexed by Global Initiative for Chronic Obstructive Lung Disease (GOLD) grades (1 versus 2 ) and are higher in those who experience frequent exacerbations. Moreover, total mucin concentrations are significantly higher in COPD patients who have either classically defined or SGRQ-defined chronic bronchitis compared with those who do not have chronic bronchitic features regardless of the presence of emphysema ${ }^{101}$.

\section{OMICS BIOMARKERS}

Omics approaches have been emerging to accelerate the discovery and development of new biomarkers in COPD (Fig. 2). One of the major advantages of this approach is the ability to ascertain truly novel biomarkers using "hypothesis-free" experiments. Large-scale genome-wide association studies (GWAS) is one such example. In a meta-analysis of four large COPD cohorts, a significant hit was identified on the locus of chromosome 19q13. These SNPs have also been associated with COPD, pre-bronchodilator (preBD) $\mathrm{FEV}_{1}$, and severe COPD in a separate cohort ${ }^{102}$. Using GWAS data, investigators found that a genetic risk score based on 95 variants that was predictive of $\mathrm{COPD}^{103}$. There are other examples: for instance, using exome sequencing to test coding genetic variants, IL-27 variant that regulates expression of mitochondrial $\mathrm{Tu}$ translation elongation factor (TUFM) was found to be significantly associated with $\mathrm{COPD}^{104}$. By applying a weighted gene co-expression network analysis (WGCNA) to peripheral blood transcriptome, two modules enriched in IL-8 and IL-10 pathway were found to be negatively associated with COPD and one module enriched in DNA transcription 
TABLE 3. Biomarkers in sputum and their main findings according to the categories

\begin{tabular}{|c|c|c|c|c|c|c|}
\hline & $\begin{array}{c}\text { Diagnosis } \\
\text { of COPD }\end{array}$ & $\begin{array}{l}\text { Monitoring } \\
\text { (severity } \\
\text { of COPD: FEV } 1 \\
\text { or presence } \\
\text { of emphysema) }\end{array}$ & $\begin{array}{l}\text { Prognosis (risk } \\
\text { of mortality, } \\
\text { rate of FEV } \\
\text { decline, } \\
\text { or progression } \\
\text { of emphysema) }\end{array}$ & $\begin{array}{l}\text { Prognosis } \\
\text { (risk of acute } \\
\text { exacerbation) }\end{array}$ & $\begin{array}{c}\text { Diagnosis } \\
\text { of acute } \\
\text { exacerbation }\end{array}$ & Comorbidity \\
\hline Neutrophil & & $\begin{array}{l}\text { Weak associa- } \\
\text { tion with } \mathrm{FEV}_{1}{ }^{97}\end{array}$ & $\begin{array}{l}\text { Association with } \\
\text { rapid decline of } \\
\mathrm{FEV}_{1}{ }^{67}\end{array}$ & & & \\
\hline Eosinophil & & $\begin{array}{l}\text { Association of } \\
\text { high sputum } \\
\text { eosinophil with } \\
\text { low } \mathrm{FEV}_{1} \text { and } \\
\text { high emphyse- } \\
\text { ma and air } \\
\text { trapping }\end{array}$ & & $\begin{array}{l}\text { Positive } \\
\text { association } \\
\text { with cortico- } \\
\text { steroid-requir- } \\
\text { ing } \mathrm{AE}^{98}\end{array}$ & & \\
\hline Defensin & $\begin{array}{l}\text { Higher in patients } \\
\text { with COPD than } \\
\text { those with } \\
\text { asthma and } \\
\text { healthy controls }{ }^{128}\end{array}$ & & & & & \\
\hline $\begin{array}{l}\text { Matrix metallo- } \\
\text { proteinase-2 } \\
\text { (MMP-2, } \\
\text { gelatinase A) } \\
\text { and prostaglan- } \\
\text { din E2 (PGE2) }\end{array}$ & Higher in COPD ${ }^{129}$ & $\begin{array}{l}\text { Inverse } \\
\text { correlation with } \\
\mathrm{FEV}_{1}{ }^{129}\end{array}$ & & & & \\
\hline Mucin & & $\begin{array}{l}\text { Association with } \\
\text { airflow } \\
\text { obstruction }_{101}\end{array}$ & & $\begin{array}{l}\text { Higher in } \\
\text { patients with } \\
\text { exacerba- } \\
\text { tions }_{101}\end{array}$ & & $\begin{array}{l}\text { Higher in } \\
\text { patients with } \\
\text { chronic } \\
\text { bronchitis }_{101}\end{array}$ \\
\hline $\begin{array}{l}\text { Neutrophil } \\
\text { gelatinase-as- } \\
\text { sociated } \\
\text { lipocalin (NGAL) }\end{array}$ & $\begin{array}{l}\text { Higher in patients } \\
\text { with ACO than } \\
\text { in those with } \\
\text { asthma or COPD } \\
\text { alone }\end{array}$ & & & & & \\
\hline $\begin{array}{l}\text { Elafin and } \\
\text { secretory } \\
\text { leukoprotease } \\
\text { inhibitor (SLPI) }\end{array}$ & & & & & $\begin{array}{l}\text { Association of lower } \\
\text { SLPI with } \\
\text { subsequent } \\
\text { bacterial infection } \\
\text { after rhinovirus } \\
\text { infection }{ }^{131}\end{array}$ & \\
\hline $\begin{array}{l}\text { Sulfatase } \\
\text { modifying } \\
\text { factor-1 (SUMF1) }\end{array}$ & $\begin{array}{l}\text { Lower in patients } \\
\text { with COPD }\end{array}$ & & & & & \\
\hline
\end{tabular}

ACO: asthma-COPD overlap; AE: acute exacerbation; COPD: chronic obstructive pulmonary disease; $\mathrm{FEV}_{1}$ : forced expiratory volume in one second.

and translation was positively associated with $\mathrm{COPD}^{105}$. Whole exome sequencing revealed that rs10859974 in CCDC38 could be a variant which attenuates lung function decline related to smoking ${ }^{106}$. Gene expression profile signatures in sputum and blood cells that have included B3GNT, LAF4, and ARHGEF10 have been associated with frequent exacerbations ${ }^{107}$. 


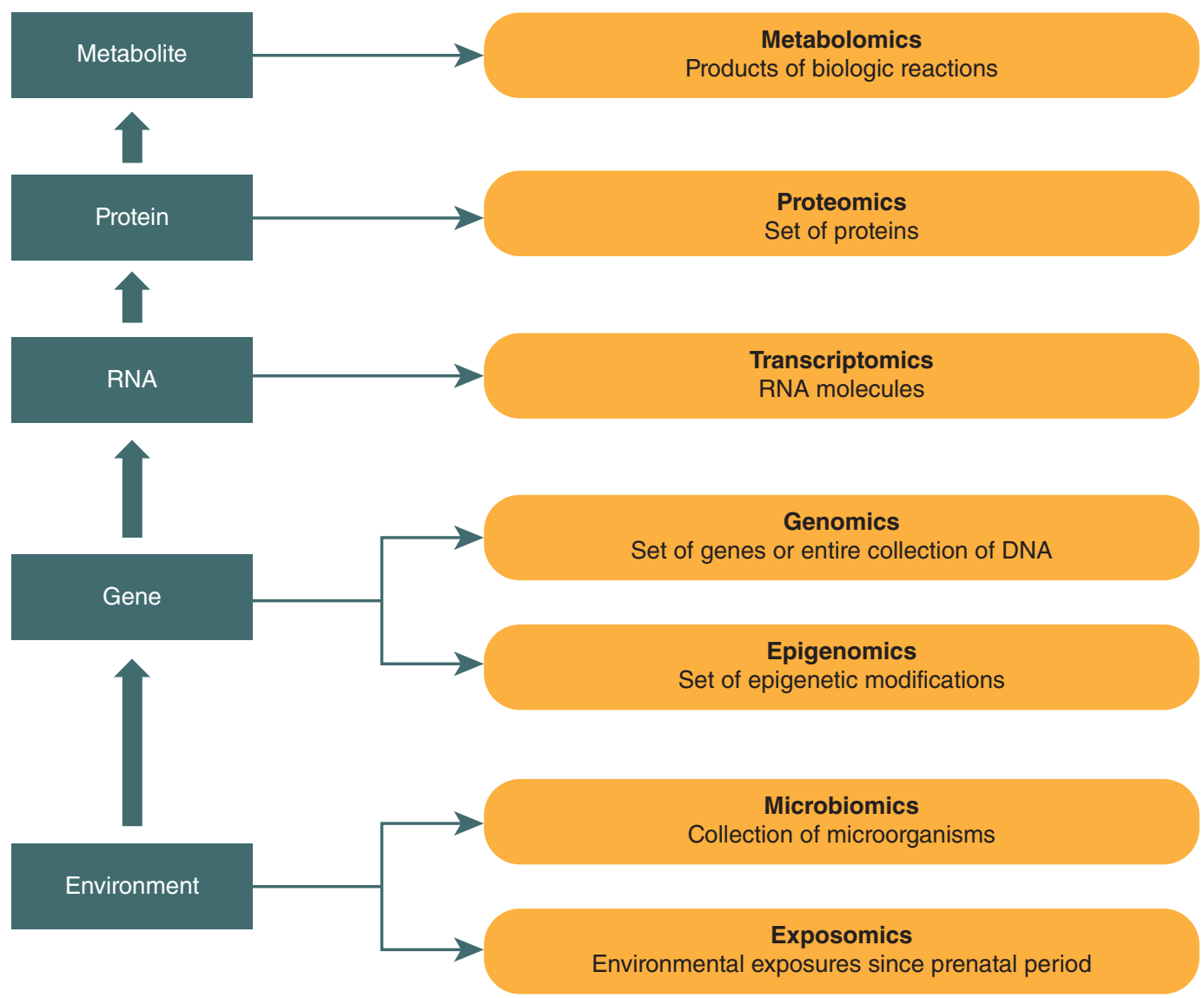

Figure 2. Example of biologic/pathological processes and corresponding kinds of omics.

At the protein level, mass spectrometry is now commonly used to discover novel biomarkers. In one study, using multiple reaction monitoring mass spectrometry, 129 blood proteins were compared in patients at the time of AECOPD versus convalescent states. Biomarker scores derived from five proteins (apolipoprotein A-IV, complement component $\mathrm{C}$, fibronectin, apolipoprotein C-II, lipopolysaccharide-binding protein) were differently expressed in blood in patients during AECOPD versus those in clinically stable conditions. The receiver operating characteristic cross-validation (CV)-AUC statistic was 0.73 in the discovery cohort, whereas the CV-AUC values were 0.77 and 0.79 in the replication cohort ${ }^{108}$. In the SPIROMICS and Genetic Epidemiology of COPD (COPDGene) cohorts, 90 blood proteins were measured by Myriad-RBM multiplex panel. A few biomarkers were replicable between these two cohorts but they added very little predictive value to clinical information for AECOPD ${ }^{109}$. When focusing on serum amino acid profiles, there were different patterns in COPD GOLD-4 versus former smoker controls; emphysema versus non-emphysema; cachexic versus non-cachexic ${ }^{110}$. Gas 
chromatography and mass spectrometry (GC/ MS) and electronic nose (eNose) identified that exhaled molecular profiles were associated with the type of inflammatory cells in mild to moderate COPD patients ${ }^{111}$.

In human lung tissue samples, an increase of the Firmicutes $(\mathrm{F})$ phylum in GOLD 4 patients compared to controls has been noted. However, the clinical relevance of flora changes in COPD lung remains unknown ${ }^{112}$. Cluster analysis of quantitative PCR in sequential sputum samples of COPD patients (stable, AECOPD, twice after AECOPD) built three clusters (high Gammaproteobacteria (G), high Firmicutes, balanced Gammaproteobacteria:Firmicutes) according to Gammaproteobacteria:Firmicutes ratio. High Gammaproteobacteria cluster had increased G:F ratio at AECOPD and decreased $\mathrm{G}: \mathrm{F}$ ratio to baseline and the elevated ratio was related to high inflammatory markers and low $\mathrm{FEV}_{1}^{113}$.

\section{IMPLEMENTATION}

Clinical implementation of biomarkers into routine clinical practice is extremely challenging. The biomarkers that have the best chance of clinical implementation are those with the following features: 1) strong performance characteristics (i.e. high sensitivity and high specificity for the endpoint in question). For example, biomarkers that have a potential for clinical translation should have a ROC AUC value of 0.7 or greater in multiple independent cohorts (Fig. 3); 2) can be easily migrated to a clinical platform where analytic validation needs to occur. This is particularly challenging for genomic biomarkers and ensemble biomarkers, which do not have obvious clinical platforms that can be used for assay development and deployment; 3) have a relatively rapid turnaround time for the assay. This is particularly important for assays that will be deployed in urgent clinics or emergency departments in which results are required within an hour or less of sample collection; 4) are relatively inexpensive. As COPD is a common disease, affecting one in four to five adults over the age of 40 years, health care payers may be hesitant to deploy very costly assays in their health care system; and most importantly 5) are actionable. Tests by themselves are not particularly useful. Only tests that modify management that improves health outcomes of patients with COPD are useful clinically. Thus, assay developers must ask the question whether the biomarkers in question are actionable and only those for which an affirmative answer can be provided should be moved along the translational pipeline $e^{5,6}$.

No blood biomarkers have been successfully implemented in clinics for the care of COPD patients. However, there are several in the pipeline that are promising. To facilitate translation, the Center for Drug Evaluation and Research (CDER) Biomarker Qualification Program has established some parameters for clinical implementation of biomarkers and for drug discovery (https://www.fda.gov/Drugs/ DevelopmentApprovalProcess/DrugDevelopmentToolsQualificationProgram/BiomarkerQualificationProgram/ucm535383.htm). The COPD Biomarker Qualification Consortium has prioritised several novel biomarkers for development including plasma/serum sRAGE, desmosine, and blood eosinophils ${ }^{114}$. In sum, for successful clinical implementation, the biomarker must have strong performance characteristics, is reproducible, can be migrated 


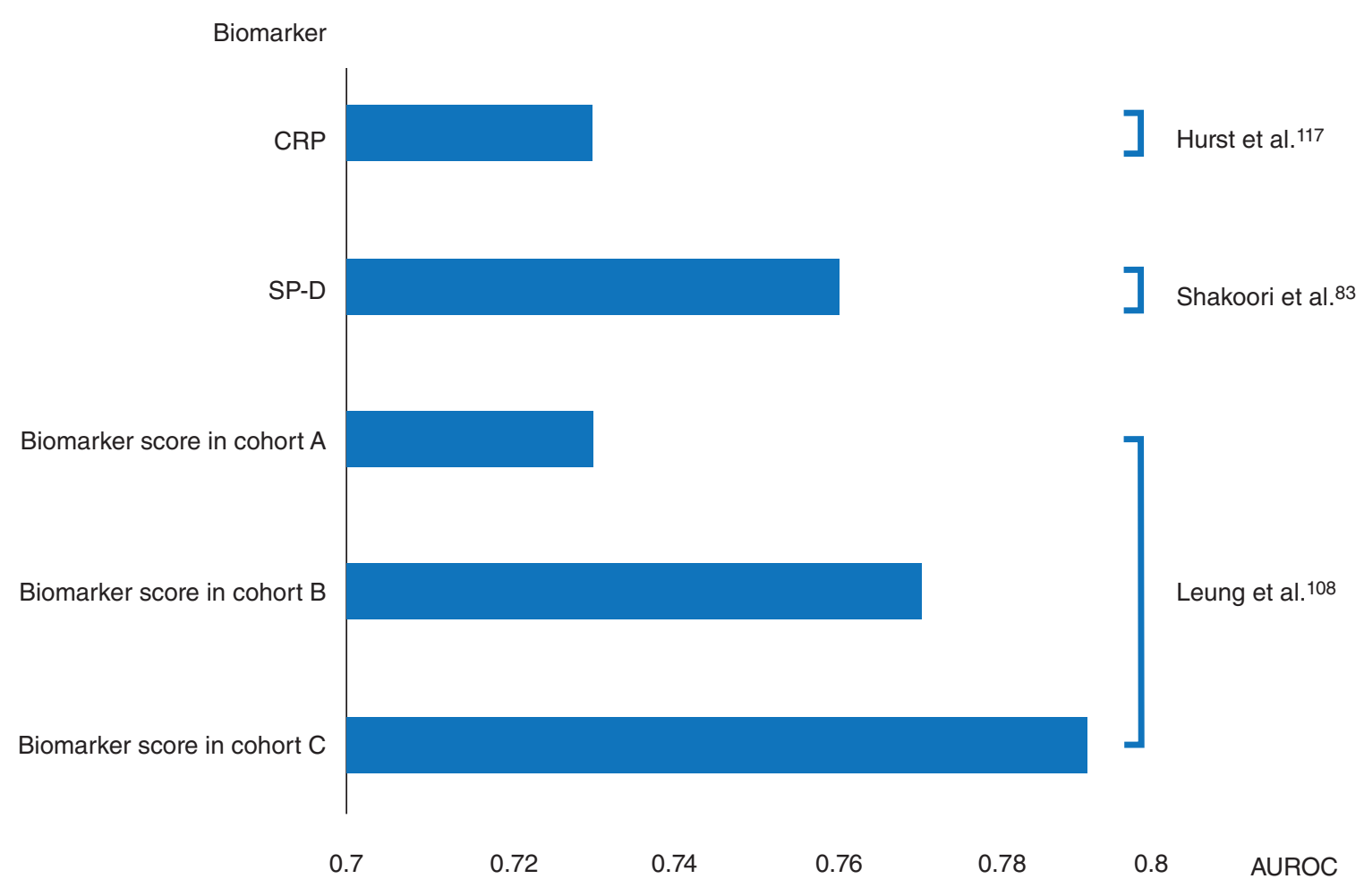

FiguRE 3. Comparison of area under the curve of the receiver operating characteristic for diagnosing acute exacerbation of chronic obstructive pulmonary disease. Biomarkers that have a potential for clinical usage should have an area under the curve of the receiver operating characteristic (ROC) values of 0.7 or greater in multiple independent cohorts (reproduced with permission from Leung JM et al. ${ }^{108}$ ) CRP: C reactive protein; SP-D: surfactant protein D.

(or developed) onto a clinically accessible platform (e.g., mass spectrometry), and is actionable. In most cases, biomarker result should modify management, which improves health outcomes and/or reduces health care costs.

\section{CONCLUSION}

COPD is a disease that is rapidly growing in prevalence and as a major cause of morbidity and mortality throughout the world. Aside from lung function measurements, there are no established biomarkers to enhance and improve patient care and their outcomes. A majority of previous studies have been limited by small sample size, poor clinical phenotyping, low performance (low signal-to-noise ratio) and lack of reproducibility/validation. Notwithstanding, there are promising candidate biomarkers on the horizon. For mortality, plasma fibrinogen and CRP singly or in combination with each other or with other molecules is promising. For disease progression, as defined by rapid decline in $\mathrm{FEV}_{1}$ or recurrent exacerbations, there are currently, no proteins or 
genes which on their own have strong enough performance characteristics to be useful clinically. To this end, use of multi-omics and multi-stage (ensemble) approaches is likely to yield more promising results in the future. Over the next five to ten years, the omics revolution coupled with improved phenotyping of patients will enable discovery of novel biomarkers to guide therapeutic choices of COPD patients and improve their health outcomes.

\section{AUTHOR'S CONTRIBUTIONS}

\begin{abstract}
All the authors contributed equally to the conception and writing of the manuscript.
\end{abstract}

\section{CONFLICT OF INTEREST}

Dr. Don D Sin has received research funding
from AstraZeneca (AZ), Boehringer Ingelheim (BI) and Merck and has received honoraria for sitting on advisory boards of AZ, BI, Regeneron, Sanofi-Aventis and Novartis and for speaking engagements from AZ, BI, Novartis and is a holder of a Tier 1 Canada Research Chair in COPD. Dr Ji-Yong Moon and Dr. You Ji Cho have no potential conflict of interest.

\section{REFERENCES}

1. Adeloye D, Chua S, Lee C et al. Global and regional estimates of COPD prevalence: Systematic review and meta-analysis. J Glob Health. 2015; 5: 020415.

2. Dwyer-Lindgren L, Bertozzi-Villa A, Stubbs RW et al. Trends and patterns of differences in chronic respiratory disease mortality among us counties, 1980-2014. JAMA. 2017;318:1136-49.

3. Labonte LE, Tan WC, Li PZ et al. Undiagnosed Chronic Obstructive Pulmonary Disease Contributes to the Burden of Health Care Use. Data from the CanCOLD Study. Am J Respir Crit Care Med. 2016;194:285-98.

4. Biomarkers Definitions Working Group. Biomarkers and surrogate endpoints: preferred definitions and conceptual framework. Clin Pharmacol Ther. 2001; 69:89-95.
5. Hollander Z, DeMarco ML, Sadatsafavi M, McManus BM, Ng RT, Sin DD. Biomarker Development in COPD: Moving From P Values to Products to Impact Patient Care. Chest. 2017;151:455-67.

6. Sin DD, Hollander Z, DeMarco ML, McManus BM, Ng RT. Biomarker Development for Chronic Obstructive Pulmonary Disease. From Discovery to Clinical Implementation. Am J Respir Crit Care Med. 2015;;192:1162-70.

7. FDA-NIH Biomarker Working Group. BEST (Biomarkers, EndpointS, and other Tools) Resource. Internet: Silver Spring (MD): Food and Drug Administration (US); 2016 [cited 2016]; Available from: https://www.ncbi.nlm. nih.gov/books/NBK326791/ ?report=classic.

8. Koo HK, Kang HK, Song P, Park HK, Lee SS, Jung H. Systemic White Blood Cell Count as a Biomarker Associated with Severity of Chronic Obstructive Lung Disease. Tuberc Respir Dis. 2017; 80:304-10.

9. Hurst JR, Vestbo J, Anzueto A et al. Susceptibility to Exacerbation in Chronic Obstructive Pulmonary Disease. New Engl J Med. 2010;363:1128-38.

10. Celli B, Locantore N, Yates J et al. Inflammatory biomarkers improve clinical prediction of mortality in chronic obstructive pulmonary disease. Am J Respir Crit Care Med. 2012;185:1065 -72.

11. Wang X, Mensinga TT, Schouten JP, Rijcken B, Weiss ST. Determinants o Maximally Attained Level of Pulmonary Function. Am J Respir Crit Care Med. 2004;169:941-9.

12. Singh D, Kolsum U, Brightling CE et al. Eosinophilic inflammation in COPD prevalence and clinical characteristics. Eur Respir J. 2014;44:1697-700.

13. Turato G, Semenzato U, Bazzan E et al. Blood Eosinophilia Does Not Reflect Tissue Eosinophils nor Worsen Clinical Outcomes in COPD. Am J Respir Crit Care Med. 2017.

14. Casanova C, Celli BR, de-Torres JP et al. Prevalence of persistent blood eosinophilia: relation to outcomes in patients with COPD. Eur Respir J. 2017;50.

15. Vedel-Krogh S, Nielsen SF, Lange P, Vestbo J, Nordestgaard BG. Blood Eosinophils and Exacerbations in Chronic Obstructive Pulmonary Disease. The Copenhagen General Population Study. Am J Respir Crit Care Med. 2016;193:965-74.

16. Pavord ID, Lettis S, Anzueto A, Barnes N. Blood eosinophil count and pneumonia risk in patients with chronic obstructive pulmonary disease: a patient-level meta-analysis. Lancet Respir Med. 2016;4:731-41.

17. Contoli M, Pauletti A, Rossi MR, Spanevello A, Casolari P, Marcellini A, et al. Long-term effects of inhaled corticosteroids on sputum bacterial and viral loads in COPD. Eur Respir J. 2017;;50.

18. Park HY, Lee H, Koh WJ, Kim S, Jeong I, Koo HK, et al. Association of blood eosinophils and plasma periostin with FEV1 response after 3-month inhaled corticosteroid and long-acting beta2-agonist treatment in stable COPD patients. Int J Chron Obstruct Pulmon Dis. 2016;11:23-30.

19. Barnes NC, Sharma R, Lettis S, Calverley PM. Blood eosinophils as a marker of response to inhaled corticosteroids in COPD. Eur Respir J. 2016;47:1374-82.

20. Pascoe S, Locantore N, Dransfield MT, Barnes NC, Pavord ID. Blood eosinophil counts, exacerbations, and response to the addition of inhaled fluticasone furoate to vilanterol in patients with chronic obstructive pulmonary disease: a secondary analysis of data from two parallel randomised controlled trials. Lancet Respir Med. 2015;3:435-42.

21. Siddiqui SH, Guasconi A, Vestbo J et al. Blood Eosinophils: A Biomarker of Response to Extrafine Beclomethasone/Formoterol in Chronic Obstructive Pulmonary Disease. Am J Respir Crit Care Med. 2015;192:523-5.

22. Pavord ID, Lettis S, Locantore $\mathrm{N}$ et al. Blood eosinophils and inhaled corticosteroid/long-acting beta-2 agonist efficacy in COPD. Thorax. 2016;71: 118-25.

23. Watz H, Tetzlaff K, Wouters EFM et al. Blood eosinophil count and exacerbations in severe chronic obstructive pulmonary disease after withdrawal of inhaled corticosteroids: a post-hoc analysis of the WISDOM trial. Lancet Respir Med. 2016;;4:390-8.

24. Roche N, Chapman KR, Vogelmeier CF, Herth FJF, Thach C, Fogel R, et al. Blood Eosinophils and Response to Maintenance Chronic Obstructive Pulmonary Disease Treatment. Data from the FLAME Trial. Am J Respir Crit Care Med. 2017;;195:1189-97. 
25. Brightling CE, Bleecker ER, Panettieri RA, Jr., Bafadhel M, She D, Ward CK, et al. Benralizumab for chronic obstructive pulmonary disease and sputum eosinophilia: a randomised, double-blind, placebo-controlled, phase 2a study. Lancet Respir Med. 2014;2:891-901.

26. Pavord ID, Chanez P, Criner GJ, Kerstjens HAM, Korn S, Lugogo N, et al. Mepolizumab for Eosinophilic Chronic Obstructive Pulmonary Disease. New Engl J Med. 2017;377:1613-29.

27. Bafadhel M, Greening NJ, Harvey-Dunstan TC et al. Blood Eosinophils and Outcomes in Severe Hospitalized Exacerbations of COPD. Chest. 2016; 150:320-8.

28. Aaron SD, Vandemheen KL, Maltais F et al. TNFalpha antagonists for acute exacerbations of COPD: a randomised double-blind controlled trial. Thorax. 2013;68:142-8.

29. Kim VL, Coombs NA, Staples KJ et al. Impact and associations of eosinophilic inflammation in COPD: analysis of the AERIS cohort. Eur Respir J. 2017;50.

30. Harrison MT, Short P, Williamson PA, Singanayagam A, Chalmers JD, Schembri S. Thrombocytosis is associated with increased short and long term mortality after exacerbation of chronic obstructive pulmonary disease: a role for antiplatelet therapy? Thorax. 2014;69:609-15.

31. Yoon HI, Li Y, Man SF, Tashkin D et al. The complex relationship of serum adiponectin to COPD outcomes COPD and adiponectin. Chest. 2012;142:893-99.

32. Suzuki M, Makita H, Östling J et al. Lower Leptin/Adiponectin Ratio and Risk of Rapid Lung Function Decline in Chronic Obstructive Pulmonary Disease. Ann Am Thorac Soc. 2014;11:1511-9.

33. Carolan BJ, Kim Y-i, Williams AA, Kechris K et al. The Association of Adiponectin with Computed Tomography Phenotypes in Chronic Obstructive Pulmonary Disease. Am J Respir Crit Care Med. 2013;188:561-6.

34. Oh YM, Jeong BH, Woo SY et al. Association of plasma adipokines with chronic obstructive pulmonary disease severity and progression. Ann Am Thorac Soc. 2015;12:1005-12.

35. Koczulla AR, Noeske S, Herr C et al. Alpha-1 antitrypsin is elevated in exhaled breath condensate and serum in exacerbated COPD patients. Respir Med. 2012;106:120-6.

36. Ingebrigtsen TS, Marott JL, Rode L, Vestbo J, Lange P, Nordestgaard BG. Fibrinogen and alpha1-antitrypsin in COPD exacerbations. Thorax. 2015;70:1014-21.

37. Horsfall LJ, Rait G, Walters K et al. Serum bilirubin and risk of respiratory disease and death. JAMA. 2011;305:691-7.

38. Apperley S, Park HY, Holmes DT et al. Serum Bilirubin and Disease Progression in Mild COPD. Chest. 2015;148:169-75.

39. Brown KE, Sin DD, Voelker H, Connett JE, Niewoehner DE, Kunisaki KM. Serum bilirubin and the risk of chronic obstructive pulmonary disease exacerbations. Respir Res. 2017;18:179.

40. Leuchte HH, Baumgartner RA, Nounou ME et al. Brain natriuretic peptide is a prognostic parameter in chronic lung disease. Am J Respir Crit Care Med. 2006;173:744-50

41. Abroug F, Ouanes-Besbes L, Nciri N et al. Association of left-heart dysfunction with severe exacerbation of chronic obstructive pulmonary disease: diagnostic performance of cardiac biomarkers. Am J Respir Crit Care Med. 2006;174:990-6

42. Patel AR, Kowlessar BS, Donaldson GC et al. Cardiovascular risk, myocardial injury, and exacerbations of chronic obstructive pulmonary disease. Am J Respir Crit Care Med. 2013;188:1091-9.

43. Lomas DA, Silverman EK, Edwards LD, Miller BE, Coxson HO, Tal-Singer R. Evaluation of serum CC-16 as a biomarker for COPD in the ECLIPSE cohort. Thorax. 2008;63:1058-63.

44. Park HY, Churg A, Wright JL et al. Club cell protein 16 and disease progression in chronic obstructive pulmonary disease. Am J Respir Crit Care Med. 2013;188:1413-9.

45. Kunisaki KM, Niewoehner DE, Singh RJ, Connett JE. Vitamin D status and longitudinal lung function decline in the Lung Health Study. Eur Respir J. 2011;37:238-43.

46. Lange NE, Sparrow D, Vokonas P, Litonjua AA. Vitamin D Deficiency, Smoking, and Lung Function in the Normative Aging Study. Am J Respir Crit Care Med. 2012;186:616-21.
47. Kunisaki KM, Niewoehner DE, Connett JE. Vitamin D levels and risk of acute exacerbations of chronic obstructive pulmonary disease: a prospective cohort study. Am J Respir Crit Care Med. 2012;185:286-90.

48. Puhan MA, Siebeling L, Frei A, Zoller M, Bischoff-Ferrari H, ter Riet G. NO association of 25-hydroxyvitamin $\mathrm{d}$ with exacerbations in primary care patients with COPD. Chest. 2014;145:37-43.

49. Kunisaki KM, Rector TS. Vitamin D and responses to inhaled fluticasone in severe chronic obstructive pulmonary disease. Int J Chron Obstruct Pulmon Dis. 2011;6:29-34.

50. Pinto-Plata V, Mullerova $\mathrm{H}$, Toso J et al. C- reactive protein in patients with COPD, control smokers, and non-smokers. Thorax. 2006;61:23-8.

51. Gan WQ, Man SFP, Senthilselvan A, Sin DD. Association between chronic obstructive pulmonary disease and systemic inflammation: a systematic review and a meta-analysis. Thorax. 2004;59:574-80.

52. Sin DD, Man SF, McWilliams A, Lam S. Progression of airway dysplasia and C-reactive protein in smokers at high risk of lung cancer. Am J Respir Crit Care Med. 2006;173:535-9.

53. Miravitlles M, Moragas A, Hernández S, Bayona C, Llor C. IS it possible to identify exacerbations of mild to moderate copd that do not require antibiotic treatment? Chest. 2013;144:1571-7.

54. Albarbarawi O, Barton A, Lin Z et al. Measurement of urinary total desmosine and isodesmosine using isotope-dilution liquid chromatography-tandem mass spectrometry. Anal Chem. 2010;82:3745-50.

55. Rabinovich RA, Miller BE, Wrobel K et al. Circulating desmosine levels do not predict emphysema progression but are associated with cardiovascular risk and mortality in COPD. Eur Respir J. 2016;47:1365-73.

56. Mannino DM, Valvi D, Mullerova H, Tal-Singer R. Fibrinogen, COPD and mortality in a nationally representative U.S. cohort. COPD. 2012;9 359-66.

57. Mannino DM, Tal-Singer R, Lomas DA et al. Plasma Fibrinogen as a Biomarker for Mortality and Hospitalized Exacerbations in People with COPD. Chron Obstr Pulm Dis. 2015;2:23-34.

58. Duvoix A, Dickens J, Haq I et al. Blood fibrinogen as a biomarker of chronic obstructive pulmonary disease. Thorax. 2013;68:670-6.

59. Dickens JA, Miller BE, Edwards LD, Silverman EK, Lomas DA, Tal-Singer R. COPD association and repeatability of blood biomarkers in the ECLIPSE cohort. Respir Res. 2011;12:146

60. Onodera K, Sugiura H, Yamada M et al. Decrease in an anti-ageing factor, growth differentiation factor 11 , in chronic obstructive pulmonary disease. Thorax. 2017;72:893-904.

61. Obeidat M, Sin DD. GDF11: a fountain of youth for the ageing COPD lung? Thorax. 2017;72:874-5

62. Sze MA, Chen YW, Tam S et al. The relationship between Helicobacter pylori seropositivity and COPD. Thorax. 2015;70:923-9.

63. Ra SW, Sze MA, Lee EC et al. Azithromycin and risk of COPD exacerbations in patients with and without Helicobacter pylori. Respir Res. 2017;18:109.

64. Kishimoto T. Interleukin-6: from basic science to medicine-40 years in immunology. Annu Rev Immunol. 2005;23:1-21.

65. He JQ, Foreman MG, Shumansky K et al. Associations of IL6 polymorphisms with lung function decline and COPD. Thorax. 2009;64:698-704.

66. Walter R, Wilk J, Larson M et al. Systemic inflammation and COPD: the Framingham Heart Study. Chest. 2008;133:19-25.

67. Donaldson GC, Seemungal TA, Patel IS et al. Airway and systemic inflammation and decline in lung function in patients with COPD. Chest. 2005 128:1995-2004.

68. Zheng J, Shi Y, Xiong L et al. The Expression of IL-6, TNF-alpha, and MCP1 in Respiratory Viral Infection in Acute Exacerbations of Chronic Obstructive Pulmonary Disease. J Immunology Res. 2017;8539294.

69. Leitao Filho FS, Won Ra S, Mattman A et al. Serum IgG and risk of exacerbations and hospitalizations in chronic obstructive pulmonary disease. J Allergy Clin Immunol. 2017;140:1164-7.

70. Savale L, Chaouat A, Bastuji-Garin S et al. Shortened telomeres in circulating leukocytes of patients with chronic obstructive pulmonary disease. Am J Respir Crit Care Med. 2009;179:566-71. 
71. Cordoba-Lanus E, Cazorla-Rivero S, Espinoza-Jimenez A et al. Telomere shortening and accelerated aging in COPD: findings from the BODE cohort. Respir Research. 2017;18:59.

72. Rutten EPA, Gopal P, Wouters EFM et al. Various Mechanistic Pathways Representing the Aging Process Are Altered in COPD. Chest. 2016;149:53-61.

73. Lee J, Sandford AJ, Connett JE et al. The relationship between telomere length and mortality in chronic obstructive pulmonary disease (COPD). PloS One. 2012;7:e35567.

74. Sin DD, Miller BE, Duvoix A et al. Serum PARC/CCL-18 concentrations and health outcomes in chronic obstructive pulmonary disease. Am J Respir Crit Care Med. 2011;183:1187-92.

75. Dilektasli AG, Demirdogen Cetinoglu E, Uzaslan E, Budak F, Coskun F, Ursavas A, et al. Serum CCL-18 level is a risk factor for COPD exacerbations requiring hospitalization. Int J Chron Obstruct Pulmon Dis. 2017;12: 199-208.

76. Mathioudakis AG, Chatzimavridou-Grigoriadou V, Corlateanu A, Vestbo J. Procalcitonin to guide antibiotic administration in COPD exacerbations: a meta-analysis. Eur Respir Rev. 2017;26.

77. Lindenauer PK, Shieh MS, Stefan MS et al. Hospital Procalcitonin Testing and Antibiotic Treatment of Patients Admitted for Chronic Obstructive Pulmonary Disease Exacerbation. Ann Am Thorac Soc. 2017;14:1779-85.

78. Foreman MG, Kong X, DeMeo DL et al. Polymorphisms in surfactant protein-D are associated with chronic obstructive pulmonary disease. Am J Respir Cell Mol Biol. 2011;44:316-22.

79. Lomas DA, Silverman EK, Edwards LD et al. Serum surfactant protein D is steroid sensitive and associated with exacerbations of COPD. Eur Respir J. 2009;34:95-102.

80. Coxson HO, Dirksen A, Edwards LD et al. The presence and progression of emphysema in COPD as determined by CT scanning and biomarker expression: a prospective analysis from the ECLIPSE study. Lancet Respir Med. 2013;1:129-36.

81. Shakoori TA, Sin DD, Ghafoor F, Bashir S, Bokhari SN. Serum surfactant protein D during acute exacerbations of chronic obstructive pulmonary disease. Dis Markers. 2009;27:287-94.

82. Smith DJ, Yerkovich ST, Towers MA, Carroll ML, Thomas R, Upham JW. Reduced soluble receptor for advanced glycation end-products in COPD. Eur Respir J. 2011;37:516-22.

83. Cheng DT, Kim DK, Cockayne DA et al. Systemic soluble receptor for advanced glycation endproducts is a biomarker of emphysema and associated with AGER genetic variants in patients with chronic obstructive pulmonary disease. Am J Respir Crit Care Med. 2013;188:948-57.

84. Man SF, Xing L, Connett JE, Anthonisen NR et al. Circulating fibronectin to $\mathrm{C}$-reactive protein ratio and mortality: a biomarker in COPD? Eur Respir J. 2008;32:1451-7.

85. Agusti A, Edwards LD, Rennard SI et al. Persistent systemic inflammation is associated with poor clinical outcomes in COPD: a novel phenotype. PloS One. 2012;7:e37483.

86. Thomsen M, Dahl M, Lange P, Vestbo J, Nordestgaard BG. Inflammatory Biomarkers and Comorbidities in Chronic Obstructive Pulmonary Disease. Am J Respir Crit Care Med. 2012;186:982-8.

87. Thomsen M, Ingebrigtsen T, Marott J et al. INflammatory biomarkers and exacerbations in chronic obstructive pulmonary disease. JAMA. 2013;309: 2353-61.

88. Janssen DJ, Mullerova H, Agusti A et al. Persistent systemic inflammation and symptoms of depression among patients with COPD in the ECLIPSE cohort. Respir Med. 2014;108:1647-54.

89. Laribi S, Pemberton CJ, Kirwan L et al. Mortality and acute exacerbation of COPD: a pilot study on the influence of myocardial injury. Eur Respir J. 2017;49.

90. Zemans RL, Jacobson S, Keene J et al. Multiple biomarkers predict disease severity, progression and mortality in COPD. Respir Res. 2017;18:117.

91. Bradford E, Jacobson S, Varasteh J et al. The value of blood cytokines and chemokines in assessing COPD. Respir Res. 2017;18:180.

92. Pinto-Plata V, Casanova C, Mullerova $\mathrm{H}$ et al. Inflammatory and repair serum biomarker pattern. Association to clinical outcomes in COPD. Respir Res. 2012;13:71.
93. Pinto-Plata V, Toso J, Lee K et al. Profiling serum biomarkers in patients with COPD: associations with clinical parameters. Thorax. 2007;62:595-601.

94. Miller BE, Tal-Singer R, Rennard SI et al. Plasma Fibrinogen Qualification as a Drug Development Tool in Chronic Obstructive Pulmonary Disease. Perspective of the Chronic Obstructive Pulmonary Disease Biomarker Qualification Consortium. Am J Respir Crit Care Med. 2016;193:607-13.

95. Stolz D, Meyer A, Rakic J, Boeck L, Scherr A, Tamm M. Mortality risk prediction in COPD by a prognostic biomarker panel. Eur Respir J. 2014; 44:1557-70.

96. Tangedal S, Aanerud M, Persson LJ, Brokstad KA, Bakke PS, Eagan TM. Comparison of inflammatory markers in induced and spontaneous sputum in a cohort of COPD patients. Respir Res. 2014;15:138.

97. Singh D, Edwards L, Tal-Singer R, Rennard S. Sputum neutrophils as a biomarker in COPD: findings from the ECLIPSE study. Respir Res. 2010; 11:77.

98. Hastie AT, Martinez FJ, Curtis JL et al. Association of sputum and blood eosinophil concentrations with clinical measures of COPD severity: an analysis of the SPIROMICS cohort. Lancet Respir Med. 2017;5:956-67.

99. Voynow JA, Rubin BK. Mucins, mucus, and sputum. Chest. 2009;135:505-12.

100. Hogg JC, Chu FS, Tan WC et al. Survival after lung volume reduction in chronic obstructive pulmonary disease: insights from small airway pathology. Am J Respir Crit Care Med. 2007;176:454-9.

101. Kesimer M, Ford AA, Ceppe A et al. Airway Mucin Concentration as a Marker of Chronic Bronchitis. The New Engl J Med. 2017;377:911-22.

102. Cho MH, Castaldi PJ, Wan ES et al. A genome-wide association study of COPD identifies a susceptibility locus on chromosome 19q13. Hum Mol Genet. 2012;21:947-57.

103. Wain LV, Shrine N, Artigas MS et al. Genome-wide association analyses for lung function and chronic obstructive pulmonary disease identify new loci and potential druggable targets. Nat Genet. 2017;49:416-25.

104. Hobbs BD, Parker MM, Chen H et al. Exome Array Analysis Identifies a Common Variant in IL27 Associated with Chronic Obstructive Pulmonary Disease. Am J Respir Crit Care Med. 2016;194:48-57.

105. Obeidat M, Nie Y, Chen V et al. Network-based analysis reveals novel gene signatures in peripheral blood of patients with chronic obstructive pulmonary disease. Respir Res. 2017;18:72.

106. Wain LV, Sayers I, Soler Artigas M et al. Whole exome re-sequencing implicates CCDC38 and cilia structure and function in resistance to smoking related airflow obstruction. PLoS Genet. 2014;10:e1004314.

107. Singh D, Fox SM, Tal-Singer R, Bates S, Riley JH, Celli B. Altered gene expression in blood and sputum in COPD frequent exacerbators in the ECLIPSE cohort. PloS One. 2014;9:e107381.

108. Leung JM, Chen V, Hollander Z et al. COPD Exacerbation Biomarkers Validated Using Multiple Reaction Monitoring Mass Spectrometry. PloS One. 2016;11:e0161129.

109. Keene JD, Jacobson S, Kechris K, Kinney GL, Foreman MG, Doerschuk CM, et al. Biomarkers Predictive of Exacerbations in the SPIROMICS and COPDGene Cohorts. Am J Respir Crit Care Med. 2017;195:473-81.

110. Ubhi BK, Cheng KK, Dong J et al. Targeted metabolomics identifies perturbations in amino acid metabolism that sub-classify patients with COPD. Mol Biosyst. 2012;8:3125-33.

111. Fens N, de Nijs SB, Peters S et al. Exhaled air molecular profiling in relation to inflammatory subtype and activity in COPD. Eur Respir J. 2011, 38:1301-9.

112. Sze MA, Dimitriu PA, Hayashi $S$ et al. The lung tissue microbiome in chronic obstructive pulmonary disease. Am J Respir Crit Care Med. 2012 185:1073-80.

113. Haldar K, Bafadhel M, Lau K et al. Microbiome balance in sputum determined by PCR stratifies COPD exacerbations and shows potential for selective use of antibiotics. PloS One. 2017;12:e0182833.

114. Rennard SI, Merrill D, Tal-Singer R, Sciurba FC. The St. George's Respiratory Questionnaire Appendix to the Food and Drug Administration Draft Guidance on COPD: Why a Small Step Forward Is So Important. Chest. 2017;152:914-6. 
115. Carter RI, Ungurs MJ, Mumford RA, Stockley RA. Aalpha-Val360: a marker of neutrophil elastase and COPD disease activity. Eur Respir J. 2013; 41:31-8.

116. American Thoracic Society/European Respiratory Society statement: standards for the diagnosis and management of individuals with alpha-1 antitrypsin deficiency. Am J Respir Crit Care Med. 2003;168:818-900.

117. Hurst J, Donaldson G, Perera W et al. Use of plasma biomarkers at exacerbation of chronic obstructive pulmonary disease. Am J Respir Crit Care Med. 2006;174:867-74.

118. Sin DD, Man SF. Why are patients with chronic obstructive pulmonary disease at increased risk of cardiovascular diseases? The potential role of systemic inflammation in chronic obstructive pulmonary disease. Circulation. 2003;107:1514-9.

119. Yohannes AM, Mullerova H, Hanania NA et al. Long-term Course of Depression Trajectories in Patients With COPD: A 3-Year Follow-up Analysis of the Evaluation of COPD Longitudinally to Identify Predictive Surrogate Endpoints Cohort. Chest. 2016;149:916-26.

120. Quint JK, Donaldson GC, Goldring JJ, Baghai-Ravary R, Hurst JR, Wedzicha JA. Serum IP-10 as a biomarker of human rhinovirus infection at exacerbation of COPD. Chest. 2010;137:812-22.

121. Park HY, Man SF, Tashkin D et al. The relation of serum myeloperoxidase to disease progression and mortality in patients with chronic obstructive pulmonary disease (COPD). PloS One. 2013;8:e61315.

122. Eagan TM, Damas JK, Ueland T et al. Neutrophil gelatinase-associated lipocalin: a biomarker in COPD. Chest. 2010;138:888-95.

123. Vogeli A, Ottiger M, Meier MA, Steuer C, Bernasconi L, Huber A, et al. Asymmetric Dimethylarginine Predicts Long-Term Outcome in Patients with Acute Exacerbation of Chronic Obstructive Pulmonary Disease. Lung. 2017;195:717-27.

124. Yanagisawa S, Papaioannou AI, Papaporfyriou A et al. Decreased Serum Sirtuin-1 in COPD. Chest. 2017;152:343-52.

125. Leung JM, Mayo J, Tan W et al. Plasma pro-surfactant protein B and lung function decline in smokers. Eur Respir J. 2015;45:1037-45.

126. Woodruff PG, Chatila W, Connett JE et al. Tumour necrosis factor receptor-75 and risk of COPD exacerbation in the azithromycin trial. Eur Respir J. 2014;43:295-8.

127. Al-shair K, Kolsum U, Dockry R, Morris J, Singh D, Vestbo J. Biomarkers of systemic inflammation and depression and fatigue in moderate clinically stable COPD. Respir Res. 2011;12:3.

128. Baines KJ, Wright TK, Simpson JL et al. Airway beta-Defensin-1 Protein Is Elevated in COPD and Severe Asthma. Mediators Inflamm. 2015;2015: 407271.

129. Chen Y, Chen P, Hanaoka M, Droma Y, Kubo K. Enhanced levels of prostaglandin E2 and matrix metalloproteinase-2 correlate with the severity of airflow limitation in stable COPD. Respirology. 2008;13:1014-21.

130. Iwamoto H, Gao J, Koskela J et al. Differences in plasma and sputum biomarkers between COPD and COPD-asthma overlap. Eur Respir J. 2014; 43:421-9.

131. Mallia P, Footitt J, Sotero R et al. Rhinovirus Infection Induces Degradation of Antimicrobial Peptides and Secondary Bacterial Infection in Chronic Obstructive Pulmonary Disease. Am J Respir Crit Care Med. 2012;186:1117-24.

132. Weidner J, Jarenback L, de Jong K et al. Sulfatase modifying factor 1 (SUMF1) is associated with Chronic Obstructive Pulmonary Disease. Respir Res. 2017;18:77. 